\title{
Lower Toarcian ammonite and foraminifera assemblages in the San Miguel de Aguayo Section (Basque-Cantabrian Basin, Spain)
}

\author{
Roselis W. Salazar-Ramírez ${ }^{1}\left[\right.$. Concha Herrero ${ }^{1} \cdot$ Antonio Goy $^{1}$
}

Received: 19 June 2019 / Accepted: 23 November 2019

(c) Universidad Complutense de Madrid 2019

\begin{abstract}
We present the biostratigraphical events, ammonites and foraminifera from the Pliensbachian (Spinatum Chronozone) to the Toarcian (Bifrons Chronozone) in San Miguel de Aguayo. We sampled the profile layer by layer for ammonites (400 specimens in 86 successive levels), and we extracted 19 samples for foraminifera (4858 picked specimens). In the Spinatum Chronozone, the Amaltheidae Family dominated, with little presence of the Arieticeratinae or Harpoceratinae. The Tenuicostatum Chronozone presents a good record of Dactylioceratinae, with successive species, from Dactylioceras (Eodactylites) simplex to Dactylioceras (Orthodactylites) semicelatum. The Serpentinum Chronozone is characterised by Harpoceratinae (Eleganticeras, Cleviceras, Harpoceras), Hildoceratinae (Hildaites, Orthildaites) and by the persistence of Dactylioceras (Orthodactylites). The Bifrons Chronozone presents a good succession of Hildoceras. The foraminifera are benthic and autochthonous, and the calcareous hyaline taxa of the Lagenina Suborder, Vaginulinidae Family, are dominant. The most diverse genera are Nodosaria and Lenticulina. The most abundant species is Lenticulina toarcense, which constitutes 55.37\% of the total number of specimens. Also represented, albeit as a minority, are the Textulariina, Miliolina, Spirillinina and Robertinina Suborders. The ammonites are typical of the Submediterranean Province and common to the Subboreal Province; the species of the Mediterranean Province are scarce and their record is sporadic in the Pliensbachian-Toarcian transition. The foraminifera are typical of the Atlantic Boreal Domain; two main biotic events were recognised: step-wise extinction of species between the Hawskerense and Semicelatum subchronozones, with a maximum extinction rate in the Semicelatum Subchronozone, and faunal turnover principally in the Elegantulum Subchronozone (Serpentinum Chronozone).
\end{abstract}

Keywords Lower Jurassic $\cdot$ Chronostratigraphy $\cdot$ Bioevents $\cdot$ Extinction $\cdot$ Pliensbachian/Toarcian boundary

\section{Resumen}

Se presenta la bioestratigrafía de los ammonoideos y foraminíferos del Pliensbachiense (Cronozona Spinatum) al Toarciense (Cronozona Bifrons) en San Miguel de Aguayo. Se levanta la columna estratigráfica y se muestrea capa a capa para ammnoideos (400 especímenes), extrayendo 19 muestras para foraminíferos (4858 ejemplares). En la Cronozona Spinatum dominan los ammonoideos de la familia Amaltheidae y son escasos los Arieticeratinae y Harpoceratinae. La Cronozona Tenuicostatum muestra buen registro de Dactylioceratinae con especies sucesivas, desde Dactylioceras (Eodactylites) simplex a Dactylioceras (Orthodactylites) semicelatum. La Cronozona Serpentinum se caracteriza por Harpoceratinae (Eleganticeras, Cleviceras, Harpoceras), Hildoceratinae (Hildaites, Orthildaites) y por la persistencia de Dactylioceras (Orthodactylites).

Roselis W. Salazar-Ramírez

roseliss@ucm.es

Concha Herrero

cherrero@geo.ucm.es

Antonio Goy

angoy@geo.ucm.es

1 Departamento de Geodinámica, Estratigrafía y

Paleontología, Facultad de Ciencias Geológicas, Universidad

Complutense de Madrid, C/ José Antonio Novais, 12,

28040 Madrid, Spain 
En la Cronozona Bifrons se registra una buena sucesión de Hildoceras. Las asociaciones de foraminíferos son bentónicas y autóctonas, siendo la Familia Vaginulinidae (Suborden Lagenina) la mejor representada. El género más abundante es Lenticulina y los más diversos Nodosaria y Lenticulina. La especie Lenticulina toarcense representa el 55,37\% del total de ejemplares. Son minoritarios los foraminíferos aglutinados (Textulariina), los aporcelanados (Miliolina), los calcáreos monocristalinos (Spirillinina) y los aragoníticos (Robertinina). Los ammonoideos son típicos de la Provincia Submediterránea y afines a la Provincia Subboreal; las especies de la Provincia Mediterránea son escasas y su registro es puntual en el tránsito Pliensbachiense-Toarciense. Los foraminíferos son típicos del Dominio Boreal Atlántico; se reconocen dos eventos bióticos: extinción escalonada de especies entre las subcronozonas Hawskerense y Semicelatum, con tasa máxima de extinción en la Subcronozona Semicelatum, y renovación y diversificación de taxones principalmente en la Subcronozona Elegantulum (Cronozona Serpentinum).

Palabras clave Jurásico Inferior · Cronoestratigrafía $\cdot$ Bioeventos · Extinciones $\cdot$ límite Pliensbachiense/Toarciense

\section{Introduction}

The municipality of San Miguel de Aguayo, to the NE of Reinosa (Cantabria Autonomous Community), presents some of the most interesting outcrops for the study of the Upper Pliensbachian and the Toarcian of the BasqueCantabrian Basin, with expanded sections and hardly any discontinuities. To date, publications on the Palaeontology of the Lower Jurassic in the San Miguel de Aguayo Section (SMA) are limited to a preliminary study by the authors of this paper presented as a poster-communication (Salazar Ramírez et al. 2015) at the Jornadas de la Sociedad Espanola de Paleontología (Congress of the Spanish Society of Palaeontology) held in 2015 in Baeza (Jaén, Spain). The present study therefore reveals for the first time the detailed succession of ammonites and foraminifera from the Upper Pliensbachian (Apyrenum Subchronozone) to the Middle Toarcian (Bifrons Subchronozone) in the SMA Section, presenting the main biotic events and crises affecting the benthic foraminifera calibrated with the standard chronostratigraphic scale of reference provided by the ammonites.

The ammonites from the Basque-Cantabrian Basin for the interval spanning from the Upper Pliensbachian (Spinatum Zone) to the Middle Toarcian (Bifrons Zone) were studied by Dahm (1965), Braga et al. (1985, 1988), Goy et al. (1994, 2006a), Perilli and Comas-Rengifo (2002), Perilli et al. (2004), among other authors. Nonetheless, few specific data are available on the biostratigraphy and chronostratigraphy of the SMA region. Portero et al. (1978), in his report on sheet number 83 (Reinosa) of the National Geological Map 1:50.000, state that the stratigraphic description of the Jurassic is based upon "the series from Reinosa and from San Miguel de Aguayo", citing the research conducted by Dahm (1965) in relation to the data on palaeontology (ammonites) and stratigraphy. The latter author, however, did not study the SMA Section but rather those in Reinosa and Ontaneda situated 12 and $28 \mathrm{~km}$ away, respectively. With regard to the interval addressed in the present research, Dahm (o.c.) cites Pleuroceras spinatum in Ontaneda, indicating that the Lower Toarcian (Tenuicostatum Zone and part of the Falciferum Zone) is shortened throughout the region. This is uncertain, as has been highlighted by Braga et al. $(1985,1988)$, Goy et al. (1994) and Quesada et al. (2005). Furthermore, Goy et al. (2006a) established a biohorizon of Dactylioceras (Orthodactylites) tenuicostatum for the Basque-Cantabrian Basin, the SMA Section constituting the reference profile for this biohorizon.

References or brief outlines of the foraminifera of the Lower Jurassic in the Basque-Cantabrian Basin can be found in the research of Ramírez del Pozo (1971a, b), Assens (1971), Villalobos (1971), Villalobos and Ramírez del Pozo (1971) and Portero et al. (1978). However, few publications provide detailed studies of the foraminifera of the Lower Jurassic, particularly for the Upper Pliensbachian-Middle Toarcian interval in the above mentioned basin. Apart from the preliminary study cited in the first paragraph of this introduction (Salazar Ramírez et al. 2015), one can only find the work of Herrero (1998) and Herrero and Salazar Ramírez (2014) for the Camino Section, of Gräfe (2005) for the Tudanca and Aguilar de Campoo sections, of Salazar Ramírez and Herrero (2015) for the San Andrés Section, and of Salazar Ramírez and Herrero (2017), who provide an abstract presenting a preliminary study of the mechanisms of taphonomic alteration observed in specimens of foraminifera from the Upper Pliensbachian-Middle Toarcian in some sections of the aforementioned basin, including SMA Section.

\section{Location and geological setting of San Miguel de Aguayo}

The section is located on the outskirts of the village of SMA, to the NE of the town of Reinosa (Fig. 1), in the PolientesTudanca trough (Quesada and Robles 1995; Robles et al. 2004), which is very close to the depocentre of the western 


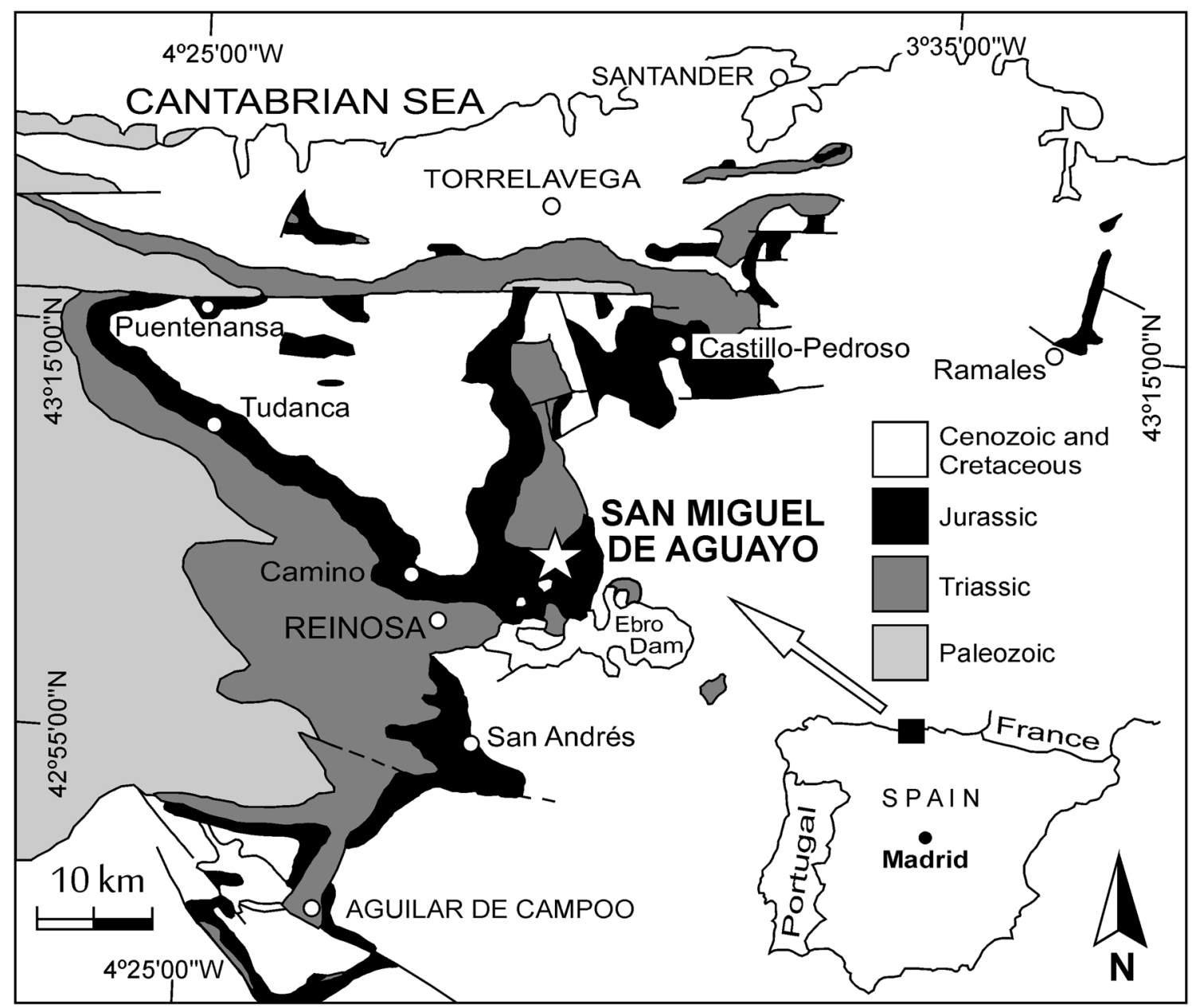

Fig. 1 Jurassic outcrops on the Western Sector of the Basque-Cantabrian Basin. The white star shows the location of the SMA Section (modified from Robles et al. 1988)

Basque-Cantabrian Basin during the Pliensbachian-Toarcian transition (see Robles et al. 2004, figs. 3.27 and 3.29a).

The section presents a thickness of approximately $33 \mathrm{~m}$ for the Upper Pliensbachian (Spinatum Chronozone, Apyrenum Subchronozone)-Middle Toarcian (Bifrons Chronozone, Bifrons Subchronozone pars). It is constituted by a rhythmic alternation of grey limestones and marly limestones with grey-to-brown marls and marlstones. These rocks are part of two lithostratigraphic units defined by Robles et al. (2002): the Limestone Mb of the Camino Formation and the Marly Mb of the Castillo Pedroso Formation, both of which the above mentioned authors interpret as being deposited on a hemipelagic carbonate ramp. They correspond to the T4-R4 and T5-R5 cycles of Quesada et al. (2005), equivalent to the LJ-3 cycle of Gómez and Goy (2005) defined for the Iberian Basin. More specifically, the interval studied corresponds to R4, T5 and to the lower part of R5, which are equivalent to the regressive part of the
LJ-3.1 cycle, to the LJ-3.2 cycle and to the transgressive part of the LJ-3.3 cycle.

\section{Materials and methods}

The bed-by-bed ammonite sampling provided 400 specimens in at least 86 successive levels (14 from the Spinatum Chronozone, 23 from the Tenuicostatum Chronozone, 24 from the Serpentinum Chronozone and 25 from the Bifrons Chronozone pars). For each level three researchers spent a minimum of one hour looking for fossils; a substantially greater amount of time was spent on the 86 beds containing ammonites. The ammonite specimens were individually labelled with the code SM, followed by the level from which they came and on occasions, when the beds were relatively thick, the ammonite specimens recovered were referred and labelled according to their distance from the bed base. 
We sampled the foraminifera in accordance with the chronostratigraphic scale of reference provided by the ammonites; whenever possible, at least two samples were collected for each ammonite subchronozone. We analysed 19 samples of marls and marlstones from the Spinatum Chronozone, Apyrenum Subchronozone, to the Bifrons Chronozone, Bifrons Subchronozone pars (Fig. 5). The whole set of samples provided over 4800 specimens that have been arranged in slides labelled with the code 1SM followed by the bed the sample came from.

The techniques for processing and extracting the foraminifera were those typically employed in micropalaeontological analyses. A total of $300 \mathrm{~g}$ of each sample rock collected in the field was processed in the laboratory. We started by breaking the marlstones into pieces measuring over 1 $\mathrm{cm}$, subsequently applying a 2- to 7-day chemical treatment with ten pellets of sodium hydroxide, $400 \mathrm{ml}$ of hydrogen peroxide and $400 \mathrm{ml}$ of distilled water. The samples were washed under running water in a sieve column with meshes measuring $1,0.5,0.25,0.125$ and $0.060 \mathrm{~mm}$. We extracted and identified the foraminifera in the 500, 250 and $125 \mu \mathrm{m}$ fractions, using a Leica/Wild M-8 stereomicroscope. The $60 \mu \mathrm{m}$ fraction only contained fragments and undeterminable juvenile specimens and was therefore not considered in the analysis. In the different samples we also identified other fossil groups accompanying the foraminifera in the residues, such as brachiopods, bivalves, gastropods, ostracods, crinoids, echinoids, holothurids, bioturbation tubes or plant remains. We arranged the foraminifera according to Loeblich and Tappan's suprageneric classification (1988).

The ammonite specimens illustrated in the present paper were whitened with a coating of magnesium oxide and subsequently photographed with a Canon 7D digital camera (105 $\mathrm{mm}$ and $60 \mathrm{~mm}$ Canon macro objective) in the photography laboratory of the Palaeontology Area belonging to the Department of Geodynamics, Stratigraphy and Palaeontology (GEODESPAL) of Madrid's Complutense University (UCM, Spain). The specimens of foraminifera were photographed with the use of the scanning electronic microscope JEOL-JSM 6400 belonging to the ICTS National Centre of Electronic Microscopy (UCM). All the specimens of ammonites, foraminifera and residues are deposited in the Palaeontology Area (GEODESPAL, UCM).

\section{Results}

The SMA Section is of great interest with regard to furthering our knowledge of the ammonites and foraminiferal assemblages in the Southwestern Sector of the BasqueCantabrian Basin. The ammonite chronostratigraphy and foraminiferal biostratigraphy had hardly been studied in the San Miguel de Aguayo area in the Upper Pliensbachian
(Spinatum Chronozone)-Middle Toarcian (Bifrons Chronozone) interval, which includes a major biotic extinction event. Thus, we analysed the ammonites and foraminiferal stratigraphical distributions (Figs. 2, 5) in order to establish the ammonite chronostratigraphical scale and the main biostratigraphic foraminiferal events. Furthermore, the foraminiferal quantitative analysis served to reveal the composition of the assemblages and the changes therein during this time interval.

\subsection{Ammonite successions}

The ammonites recorded in the SMA Section are conserved as internal moulds that are rarely complete. They almost always present an infill similar to the rock matrix in which they became fossilised and only occasional evidence of reelaboration (reworking) has been detected in the SM-114 level. This bed might be equivalent to the CM-276 level from the Camino Section (Cantabria) in which Goy et al. (1994) identify a regional discontinuity in beds corresponding to the lower part of the Bifrons Subchronozone, and which can be recognised throughout most of the Basque-Cantabrian Basin. In the specimens, the first whorls of the phragmocone are sometimes not infilled but rather are cemented. This is likely due to the fact that the sedimentation rate is relatively high in the transgressive part of the T5-R5 cycle, which is situated in the upper part of the Semicelatum Subchronozone and the lower part of the Bifrons Subchronozone, a fact that prevents the specimens from being completely infilled.

The succession of ammonite assemblages obtained (Fig. 2) enabled recognition of four chronozones and eight subchronozones of the Chronostratigraphic Standard Scale of the Submediterranean Province sensu Page (2003).

In the Upper Pliensbachian, Spinatum Chronozone, the ammonites are dominated by Amaltheidae (Amaltheus, Pleuroceras and Amauroceras), followed by a small number of Arieticeratinae (Canavaria, Tauromeniceras) and Harpoceratinae (Protogrammoceras, Lioceratoides, Neolioceratoides). The Apyrenum Subchronozone is characterised by the frequent presence of Pleuroceras solare (Fig. 3a), early associated with Pleuroceras spinatum (Fig. 3c) which is also common in other sections of N Iberia (Comas-Rengifo 1982; Comas-Rengifo et al. 2016), although morphologies within the range of variability of $P$. spinatum have been recorded in older levels. The presence of Pleuroceras cf. apyrenum (Fig. 3b) characterises the Apyrenum Subchronozone. The species Amaltheus cf. margaritatus, which persisted throughout most of the Apyrenum Subchronozone in the Basque-Cantabrian Basin, has also been recorded.

The Hawskerense Subchronozone was characterised by the presence of the index species Pleuroceras hawskerense (Fig. 3d), associated with P. spinatum and occasionally with Amauroceras sp. Following the last record of Pleuroceras 


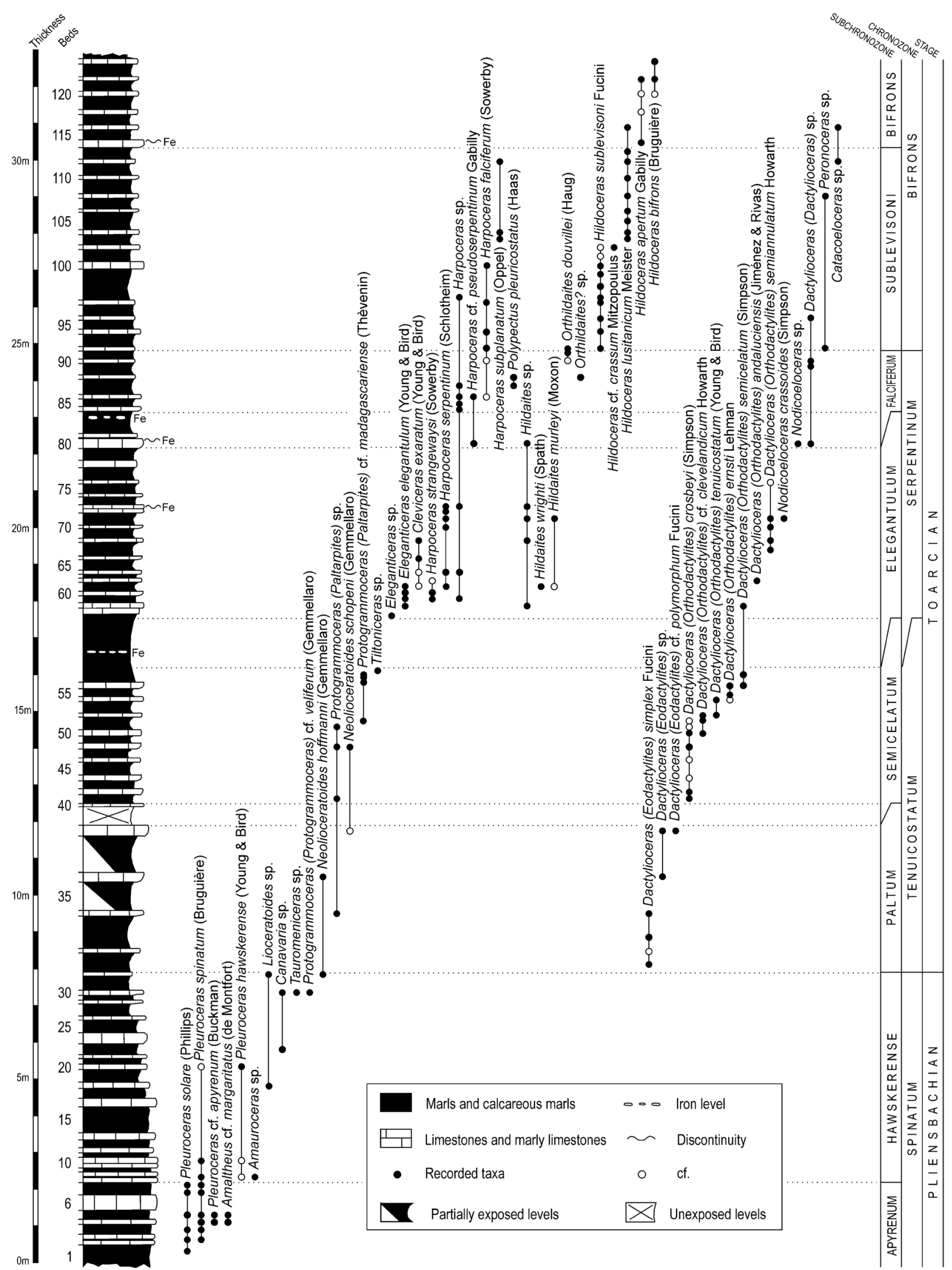

Fig. 2 Ammonite range chart in the SMA Section with the chronostratigraphic reference scale, chronozones and subchronozones, used in this paper 


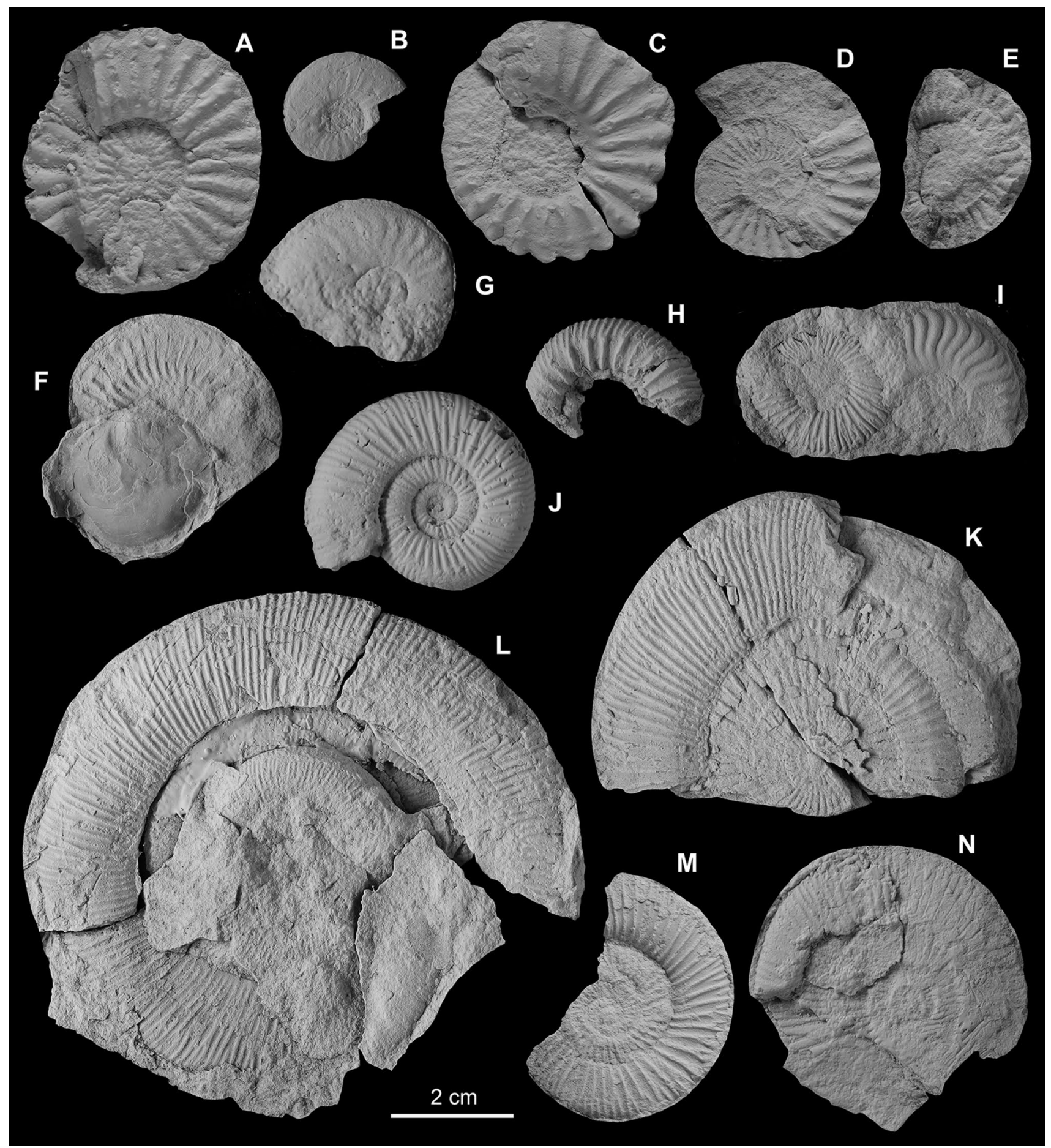

Fig. 3 Upper Pliensbachian-Middle Toarcian selected ammonites from the SMA Section. a Pleuroceras solare (Phillips) SM-2.1, Apyrenum Subchronozone. b Pleuroceras cf. apyrenum (Buckman) SM-5.7, Apyrenum Subchronozone. c Pleuroceras spinatum (Bruguière) SM-7.3, Apyrenum Subchronozone. d Pleuroceras hawskerense Howarth SM-20.4, Hawskerense Subchronozone. e Canavaria sp. SM-30.3, Hawskerense Subchronozone. f Tauromeniceras sp. SM-30.4, Hawskerense Subchronozone. g Neolioceratoides hoffmanni (Gemmellaro) SM-31.3, Hawskerense Subchronozone. h Dactylioceras (Eodactylites) simplex Fucini SM-31 (+0.7 m from the bed base), Paltum Subchronozone. i Dactylioceras (Orthodactylites) crosbeyi (Simpson) and Neolioceratoides cf. schopeni (Gemmellaro) SM-48.5, Semicelatum Subchronozone, left and right specimens, respectively. j Dactylioceras (Orthodactylites) cf. clevelandicum Howarth SM-52.4, Semicelatum Subchronozone. k Dactylioceras (Orthodactylites) tenuicostatum (Young and Bird) SM-52.1, Semicelatum Subchronozone. I Dactylioceras (Orthodactylites) semicelatum (Simpson) SM-56.7, Semicelatum Subchronozone. m Dactylioceras (Orthodactylites) ernsti Lehman SM-55.1, Semicelatum Subchronozone. n Dactylioceras (Orthodactylites) semiannulatum Howarth SM-67.1, Elegantulum Subchronozone 
and prior to the first record of Dactylioceras, which marks the start of the Toarcian Stage in the Mediterranean Province (Ferreti 1970, 1972; Rivas 1972; Guex 1973; Elmi et al. 1974; Jiménez and Rivas 1981; Goy et al. 1988; Parisi et al. 1998; Bilotta et al. 2010) and in the Submediterranean Province (Elmi et al. 1989, 1997, 2010; Goy et al. 1988, 1994, 1998, 2006b; Elmi 2006; Comas-Rengifo et al. 2010a, b; Rocha et al. 2016; Duarte et al. 2018a, b), one can find Canavaria sp. (Fig. 3e), Tauromeniceras sp. (Fig. 3f), Protogrammoceras (Protogrammoceras) cf. veliferum and Neolioceratoides hoffmanni (Fig. 3g) .

The Lower Toarcian, Tenuicostatum Chronozone, is characterised by the abundance of Dactylioceratidae. Successive records of Dactylioceras (Eodactylites) simplex (Fig. 3h), D. (E.) polymorphum, D. (Orthodactylites) crosbeyi (Fig. 3i, left), D. (O.) tenuicostatum (Fig. 3k) and D. (O.) semicelatum (Fig. 31) have been obtained. The first two species and the first Protogrammoceras (Paltarpites) sp. recorded correspond to the Paltum Subchronozone, in whose upper part can be found a small number of Harpoceratinae such as Neolioceratoides hoffmanni and N. cf. schopeni (Fig. 3i, right). The other three species of Dactylioceras correspond to the Semicelatum Subchronozone, in which $D$. (O.) cf. clevelandicum (Fig. 3j) and D. (O.) ernsti (Fig. 3m) have been recorded and, in whose upper part Protogrammoceras (Paltarpites) cf. madagascariense has also been recorded.

The Serpentinum Chronozone is characterised by the presence of the Harpoceratinae Subfamily and specifically by Eleganticeras, Cleviceras and Harpoceras, by the scarcity of the genus Hildaites (Hildoceratinae Subfamily) and by the persistence of $D$. (Orthodactylites) in the Elegantulum Subchronozone. The lower boundary of the chronozone is marked by the first record of Eleganticeras elegantulum (Fig. 4a) which, together with Cleviceras exaratum (Fig. 4b), characterise the Elegantulum Subchronozone. Also recorded in this subchronozone were Harpoceras strangewaysi and Harpoceras serpentinum (Fig. 4c), Hildaites $\mathrm{cf}$. wrighti (Fig. 4e), Hildaites murleyi (Fig. 4f), Dactylioceras (Orthodactylites) andaluciensis, D. (O.) semiannulatum (Fig. 3n), Nodicoeloceras crassoides and Dactylioceras (Dactylioceras) sp.

In most of the Falciferum Subchronozone the ammonites are scarce, corresponding to Harpoceratinae of the genus Harpoceras and to Dactylioceratinae of the subgenus $D$. (Dactylioceras). Nonetheless, in the uppermost part of the subchronozone it has been observed the dominance of Hildoceratinae of the genus Orthildaites, such as $O$. douville $i$ (Fig. 4g), which allows the correlation between the Subboreal and Submediterranean Provinces, on one hand, and certain areas of the Mediterranean Province, on the other, such as the Betic Cordillera (Goy et al. 1988) and the Apennines (Cresta et al. 1995; Macchioni and Cecca 2002; Bilotta et al. 2010).
The Middle Toarcian, Bifrons Chronozone pars (the present research does not address the Variabilis Chronozone) is characterised by the presence of abundant Hildoceras, H. sublevisoni (Fig. 4h) and H. lusitanicum (Fig. 4i, j) in the Sublevisoni Subchronozone, and H. apertum (Fig. 4k) and $H$. bifrons in the Bifrons Subchronozone. The remaining ammonite taxa represent a small fraction of all the specimens recorded. In the Sublevisoni Subchronozone it has been recorded Harpoceras of the species $H$. falciferum (Fig. 4d), together with $H$. sublevisoni, and Harpoceras subplanatum. This last species coexists with $H$. lusitanicum, and occasionally with Dactylioceratinae of the genera Peronoceras sp. (Fig. 4l) and Catacoeloceras sp. In the lower part of the Bifrons Subchronozone, H. apertum can be found together with Catacoeloceras.

\subsection{Foraminiferal successions: main biostratigraphic events}

A total of 4858 specimens were counted in the 19 samples studied in the SMA Section. Due to the state of conservation of some of the specimens, 67 of them were attributed to the genus level, as the species could not be assigned, 118 were classified only at the family level, four specimens were included within the informal category of adherent foraminifera, and 162 could not be ascribed to any taxonomic category. We identified five suborders, 11 families, 24 genera and 67 species. The benthic calcareous foraminifera dominate practically all the assemblages and the agglutinated ones can be considered as an accessory group, except for level 1SM.57T, in which they represent $84.06 \%$ of the specimens. The involuted planispiral lenticular morphologies are by far dominant in the material studied, followed by mixed growth shells, from planispiral to straight, and arched uniserial ones.

Qualitative assessment of the assemblages revealed a moderate-to-good state of conservation; this is justified by the high percentage of specimens classified at the species level. However, the foraminifera are affected by different mechanisms of taphonomic alteration that acted-with varying degrees of intensity-both in the biostratinomic and fossildiagenetic phases. In certain levels, the effect of these mechanisms hindered the picking process and the subsequent classification; this occurred, for instance, with the specimens of sample 1SM.1, in which the dissolution and fragmentation were more noteworthy.

The taphonomic features affecting the foraminifera are similar to those described by Herrero (1992) and Herrero and Canales (2002) for the Lower and Middle Jurassic in the Iberian Range and the Basque-Cantabrian Basin. They include: incipient or advanced corrasion giving rise to polished surfaces and small holes that present irregular shapes; fragmentation-partial or generalised-most frequently 


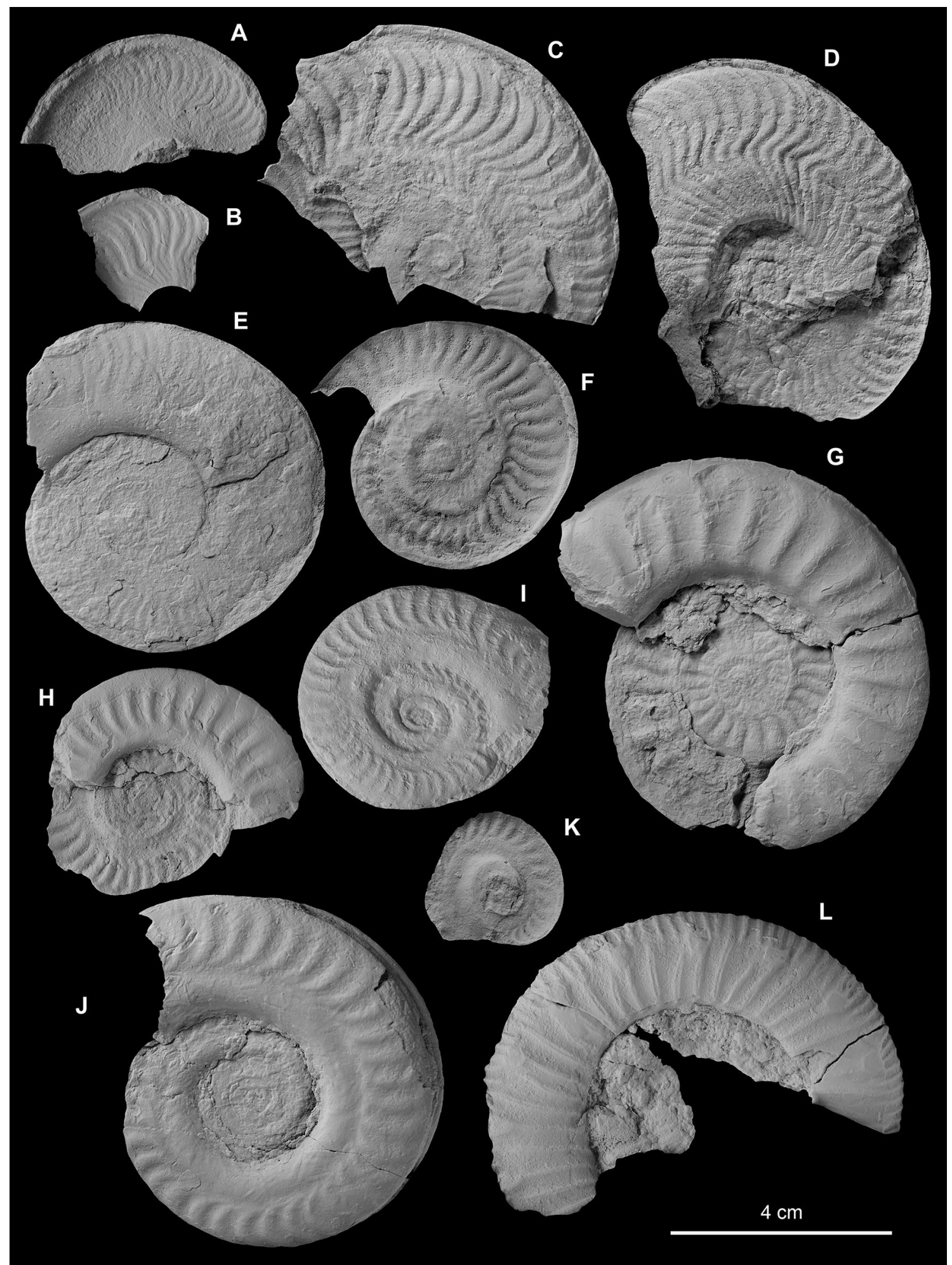

Fig. 4 Upper Pliensbachian-Middle Toarcian selected ammonites from the SMA Section. a Eleganticeras elegantulum (Young and Bird) SM-60.1, Elegantulum Subchronozone. b Cleviceras exaratum (Young and Bird) SM-68.2, Elegantulum Subchronozone. c Harpoceras serpentinum (Schlotheim) SM-64.2, Elegantulum Subchronozone. d Harpoceras falciferum (Sowerby) SM-90.6, Falciferum Subchronozone. e Hildaites cf. wrighti (Spath) SM-61.7, Elegantulum Subchronozone. f Hildaites murleyi (Moxon) SM-71.4, Elegantu- lum Subchronozone. g Orthildaites douvillei (Haug) SM-91T.5, Falciferum Subchronozone. h Hildoceras sublevisoni Fucini SM-94.5, Sublevisoni Subchronozone. i Hildoceras lusitanicum Meister SM-108.5, Sublevisoni Subchronozone. j Hildoceras lusitanicum Meister SM-112.5, Sublevisoni Subchronozone. k Hildoceras apertum Gabilly SM-122.5, Bifrons Subchronozone. 1 Peronoceras sp. SM-92.12, Sublevisoni Subchronozone 
affecting the proloculus, first and last chambers in uniserial shells (e.g. Paralingulina tenera, Prodentalina terquemi and Marginulina prima), and the last chambers and the periphery in planispiral and mixed shells (e.g. Lenticulina polygonata and Astacolus chicheryi); abrasion with rounded edges in fragmented specimens (e.g. Prodentalina terquemi), obliteration of the sutural reliefs (e.g. Astacolus chicheryi and Lenticulina helios) and erosion of the ribs (e.g. Ichthyolaria sulcata and Planularia inaequistriata); frequent micritic infillings and sparite and iron sulphide cementation inside the chambers; incipient or partial dissolution of the shell surface affecting the septa, keels and ornamentation, and sometimes exposing the chamber infillings (e.g. Lenticulina toarcense and Saracenella sublaevis); dissolution of aragonitic shells in the fossildiagenetic phase with the specimens preserved as internal moulds (e.g. Ceratobuliminidae Family); frequent carbonate crusts with differentsized crystals partially or almost totally covering the surface of some specimens (e.g. Falsopalmula jurensis) and to a lesser degree, partial coatings of limonitized sulphurs (e.g. Astacolus matutinus); and finally, deformation and distortion affecting the shape and dimensions of the shells (e.g. Marginulina prima and Pseudonodosaria vulgata) and of the internal moulds assigned to the Ceratobuliminidae Family.

We will now describe the most relevant variations in the vertical distribution of the taxa, taking as a reference framework the ammonite chronostratigraphic reference scale. The succession of foraminiferal assemblages is represented in Fig. 5 and the most representative species are illustrated in Figs. 6 and 7. On examining changes in the stratigraphic distributions of certain taxa in terms of first and last appearances in the Upper Pliensbachian-Middle Toarcian of the SMA Section, several significant biostratigraphic events have been identified. As described below, this interval saw the extinction of some typical Pliensbachian species of the genera Astacolus, Planularia, Ichthyolaria, Marginulina, Mesodentalina, Paralingulina, Prodentalina, Saracenella, and the first record of characteristic Toarcian species of the genera Falsopalmula, Astacolus, Citharina, Planularia, Ichthyolaria and Nodosaria.

The extinction bioevent occurred in a stepwise mode, starting in the upper part of the Spinatum Chronozone and becoming more intense in the Tenuicostatum Chronozone, specifically in the Semicelatum Subchronozone, where the highest extinction rate was observed to occur. Thus, Planularia inaequistriata (Fig. 6a) and Astacolus speciosus (Fig. 6b) present their last record at the top of the Hawskerense Subchronozone (sample 1SM.27); Astacolus matutinus (Fig. 6h), Ichthyolaria sulcata (Fig. 6i), Marginulina cf. interrupta and Mesodentalina cf. matutina are found for the last time in the lower part of the Paltum Subchronozone (sample 1SM.33m/s); Planularia pulchra (Fig. 6j) disappears in the lower part of the Semicelatum Subchronozone (sample 1SM.45T), whereas Marginulina prima (Fig. 6k), Prodentalina terquemi (Fig. 61), Paralingulina tenera (Fig. 6m), Saracenella sublaevis (Fig. 6n), Ichthyolaria intumescens (Fig. 6g) and Marginulina cf. spinata disappear in the middle part of this subchronozone (sample 1SM.51).

In the SMA Section we also identified two short-range species, Eoguttulina palomerensis (Fig. 6e) and Saracenella aragonensis, which characterise the Pliensbachian-Toarcian transition (sample 1SM.27 to sample 1SM.51) and the Tenuicostatum Chronozone (1SM.51), respectively.

Some typically Toarcian species, such as Falsopalmula jurensis (Fig. 7b), appear in the Semicelatum Subchronozone; however, the most relevant faunal turnover of taxa started at the base of the Elegantulum Subchronozone (sample 1SM.61) with the appearance of the genus Citharina and the species Citharina cf. colliezi. Also recorded for the first time at this level were other species typical of the Toarcian, such as Astacolus chicheryi (Fig. 7g) and Planularia chicheryi (Fig. 7f). Presenting their first record, too, within the Elegantulum Subchronozone were the species Citharina iberica (Fig. 7h), Falsopalmula chicheryi and Lenticulina helios (Fig. 7i) in sample 1SM.67, and Citharina clathrata (Fig. 7j) in sample 1SM.77. In the Falciferum Subchronozone (sample 1SM.87) Ichthyolaria hauffi has been identified for the first time, and Citharina gradata and Nodosaria cf. byfieldensis were first recorded in the Bifrons Subchronozone (sample 1SM.123).

We also wish to emphasize the fact that several species present a continuous record along the stratigraphic interval studied such as Planularia cordiformis (Fig. 7k), P. protracta (Fig. 7e), Lenticulina bochardi, L. polygonata (Fig. 7o), L. toarcense (Fig. 7n), Nodosaria hortensis (Fig. $7 \mathrm{~m}$ ), Prodentalina subsiliqua (Fig. 71), and Pseudonodosaria vulgata (Fig. 6f), whereas other species like Nodosaria mitis or Berthelinella involuta (Fig. 6p) exhibit single records in the Spinatum and Tenuicostatum chronozones, respectively. The taxa Ammobaculites barrowensis (Fig. 6d), Ceratobuliminidae Family (Fig. 6o) and Ichthyolaria squamosa (Fig. 6c) are present in both Spinatum and Tenuicostatum chronozones. It should be pointed out that adherent foraminifera attached to fragments of invertebrates or to foraminiferal shells were only identified in the samples corresponding to Spinatum Chronozone of the Pliensbachian (Fig. 5); additionally, Eoguttulina liassica (Fig. 7a), Spirillina infima (Fig. 7c) and Falsopalmula obliqua (Fig. 7d) have only been recorded in the Toarcian.

\subsection{Quantitative analysis of the foraminiferal assemblages}

In the SMA Section, the number of genera per sample ranges from 2 to 19, whereas the number of species (species richness) is between 3 and 28 (Fig. 5). The levels exhibiting 


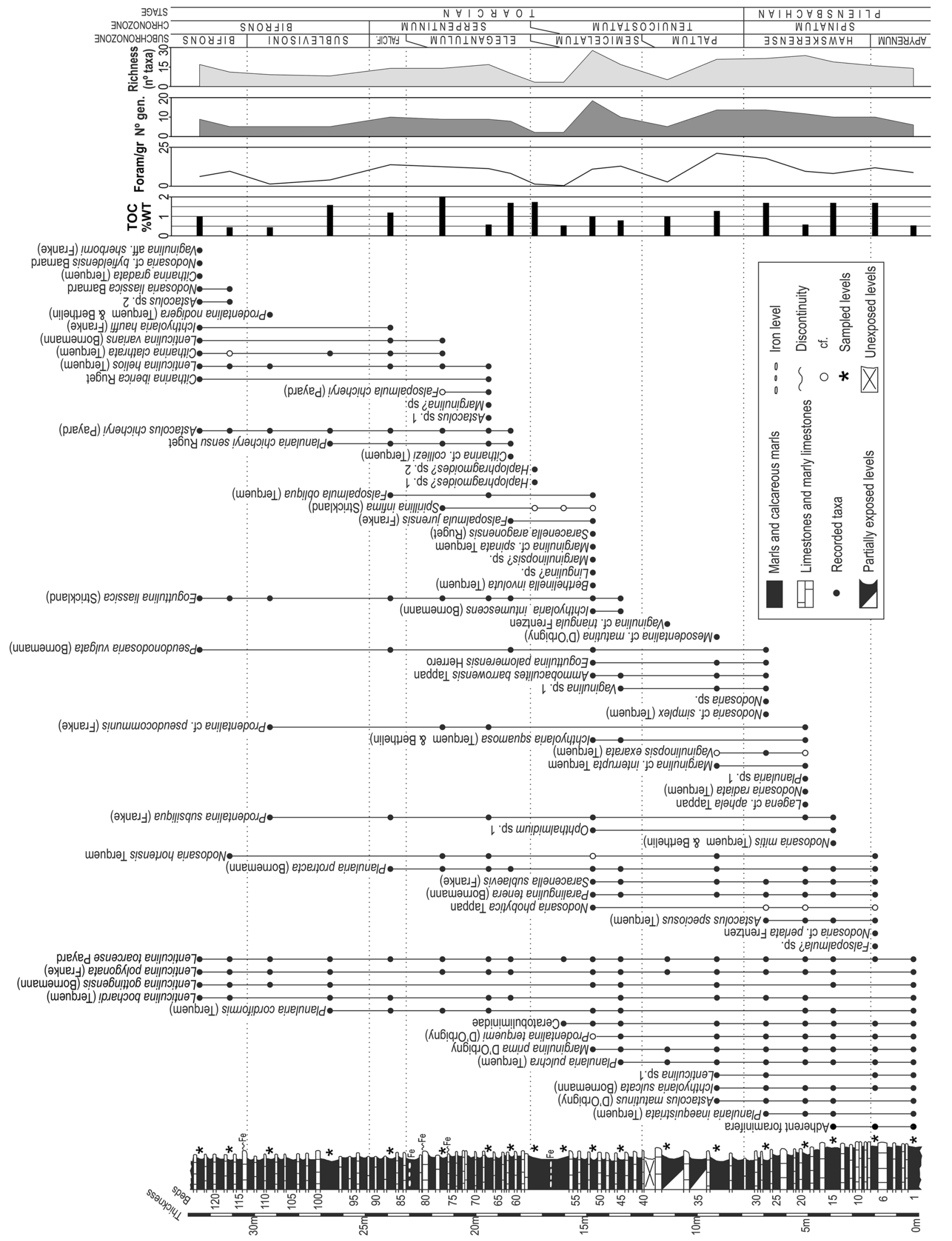




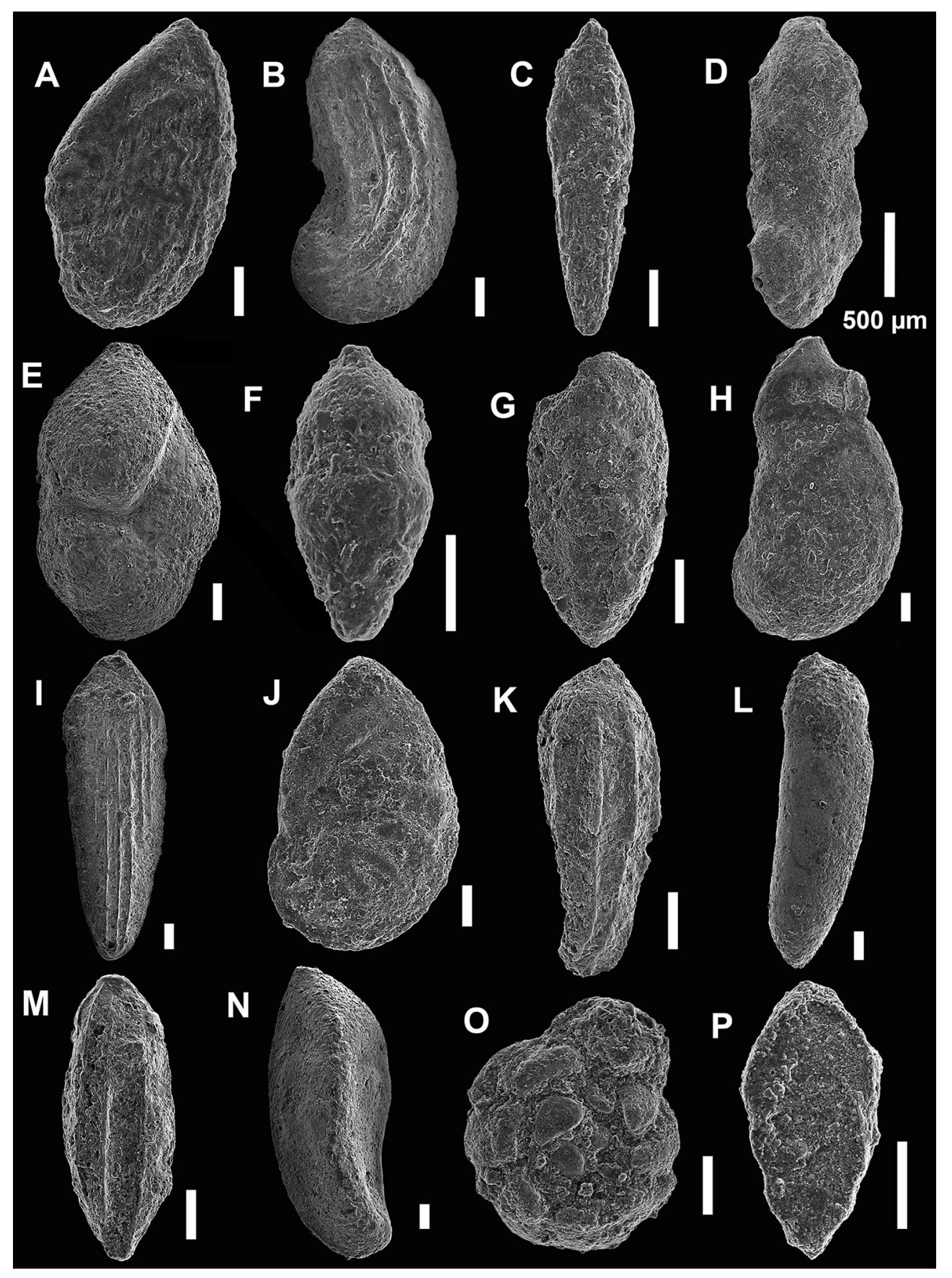

Fig. 6 Upper Pliensbachian-Middle Toarcian selected foraminifera from the SMA Section. Scale bars $=100 \mu \mathrm{m}$ (unless stated otherwise). a Planularia inaequistriata (Terquem), 1SM.1.1838, Apyrenum Subchronozone. b Astacolus speciosus (Terquem), 1SM.19.1712, Hawskerense Subchronozone. c Ichthyolaria squamosa (Terquem and Berthelin), 1SM.19.1760, Hawskerense Subchronozone. d Ammobaculites barrowensis Tappan, 1SM.33m/s.1777, Paltum Subchronozone. e Eoguttulina palomerensis Herrero, 1SM.27.1713, Hawskerense Subchronozone. f Pseudonodosaria vulgata (Bornemann), 1SM.27.1768, Hawskerense Subchronozone. g Ichthyolaria intumescens (Bornemann), 1SM.51.1741, Semicelatum
Subchronozone. h Astacolus matutinus (D’Orbigny), 1SM.15.1747, Hawskerense Subchronozone. i Ichthyolaria sulcata (Bornemann), 1SM.15.1719, Hawskerense Subchronozone. j Planularia pulchra (Terquem), 1SM.33m/s.1774, Paltum Subchronozone. k Marginulina prima D'Orbigny, 1SM.33m/s.1729, Paltum Subchronozone. I Prodentalina terquemi (D’Orbigny), 1SM.19.1718, Hawskerense Subchronozone. m Paralingulina tenera (Bornemann), 1SM.15.1727, Hawskerense Subchronozone. n Saracenella sublaevis (Franke), 1SM.19.1706, Hawskerense Subchronozone. o Ceratobuliminidae, 1SM.19.1757, Hawskerense Subchronozone. p Berthelinella involuta (Terquem), 1SM.51.1792, Semicelatum Subchronozone 


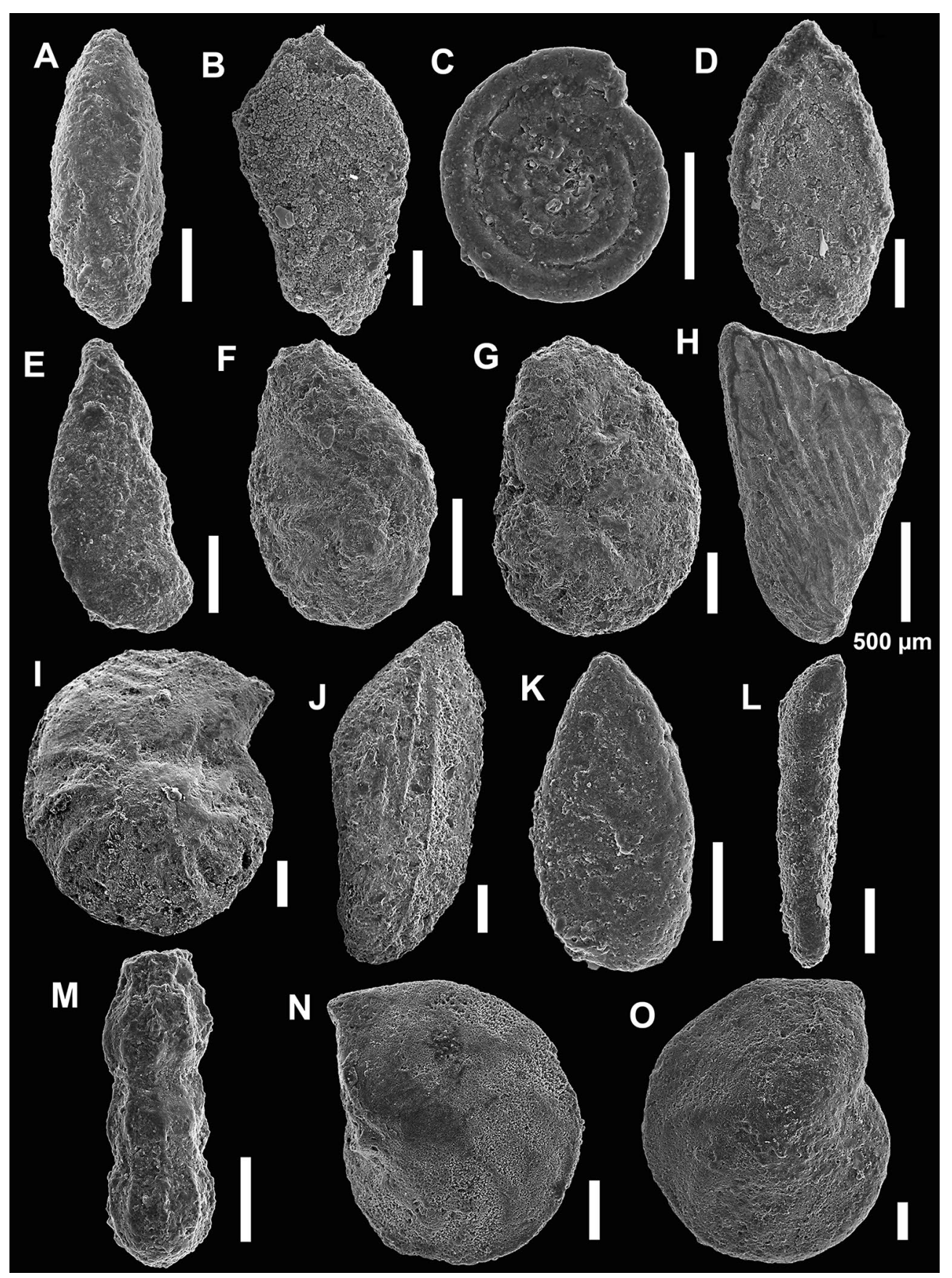

Fig. 7 Upper Pliensbachian-Middle Toarcian selected foraminifera from the SMA Section. Scale bars $=100 \mu \mathrm{m}$ (unless stated otherwise) a Eoguttulina liassica (Strickland), 1SM.117.1828, Bifrons Subchronozone. b Falsopalmula jurensis (Franke), 1SM.61.2133, Elegantulum Subchronozone. c Spirillina cf. infima (Strickland), 1SM.57T.1877, Semicelatum Subchronozone. d Falsopalmula obliqua (Terquem), 1SM.51.1868, Semicelatum Subchronozone. e Planularia protracta (Bornemann), 1SM.45T.1784, Semicelatum Subchronozone. f Planularia chicheryi sensu Ruget, 1SM.77.1739, Elegantulum Subchronozone. g Astacolus chicheryi (Payard),
1SM.67.1726, Elegantulum Subchronozone. h Citharina iberica Ruget, 1SM.123.1899, Bifrons Subchronozone. i Lenticulina helios (Terquem), 1SM.87.1714, Falciferum Subchronozone. j Citharina clathrata (Terquem), 1SM.77.1722, Elegantulum Subchronozone. k Planularia cordiformis (Terquem), 1SM.15.1753, Hawskerense Subchronozone. I Prodentalina subsiliqua (Franke), 1SM.87.1816, Falciferum Subchronozone. m Nodosaria hortensis Terquem, 1SM.67.1886, Elegantulum Subchronozone. n Lenticulina toarcense Payard, 1SM.1.1744, Apyrenum Subchronozone. o Lenticulina polygonata (Franke), 1SM.33m/s.1771, Paltum Subchronozone 
the lowest number of genera and the lowest degree of richness correspond to samples 1SM.57B and 1SM.57T (upper part of the Semicelatum Subchronozone), whereas sample 1SM.51 (middle part of the Semicelatum Subchronozone) provides the maximum values for number of genera and species. The number of foraminifera per gram of sediment is low, presenting values that range from 0.12 to 21.22 (Fig. 5). The minimum value of this ratio is recorded in sample 1SM.57B (upper part of the Semicelatum Subchronozone) and the maximum is detected in sample $1 \mathrm{SM} .33 \mathrm{~m} / \mathrm{s}$ (lower part of the Paltum Subchronozone).

Moreover, Total Organic Carbon (TOC) concentrations are low, ranging from 0.45 to $2 \%$ throughout the stratigraphic interval considered. The highest TOC value was recorded in the upper part of the Elegantulum Subchronozone and the lowest percentages correspond to the transition between the Sublevisoni and Bifrons subchronozones. As shown in Fig. 5, no clear negative correlation can be observed between the increase of TOC values and the decrease of richness and abundance.

Most of the foraminifera obtained in the Pliensbachian-Toarcian transition of the SMA Section are included within the Lagenina Suborder (92.38\%), although a small number of specimens and species have been identified as belonging to the Robertinina (2.43\%), Textulariina $(1.56 \%)$, Spirillinina $(0.16 \%)$ and Miliolina $(0.04 \%)$ suborders. The assemblage of sample 1SM.51 (Tenuicostatum Chronozone, Semicelatum Subchronozone) is the only one in which specimens belonging to the five suborders are simultaneously recorded.

The Lagenina Suborder presents relative frequencies greater than $81 \%$ in most of the assemblages, except in sample 1SM.57B, in which this suborder displays a relative abundance of $11.11 \%$, and sample 1SM.57T, in which no specimens were seen to be attributable to this suborder. In 8 of the 19 levels sampled (samples 1SM.37T, 1SM.61, 1SM.67, 1SM.87, 1SM.99, 1SM.109, 1SM.117 and 1SM.123), all the specimens identified belong to the Lagenina Suborder (Fig. 5). Additionally, 6 families were observed to present different distributions and trends within this suborder. The Vaginulinidae Family is the best represented $(82.32 \%)$, its relative abundance gradually increasing towards the Bifrons Subchronozone; the contrary occurs with the Ichthyolariidae Family (7.82\%), whose relative frequency decreases towards the latter subchronozone. The Nodosariidae (1.32\%) and Polymorphinidae (0.66\%) families present low relative percentages in all subchronozones; the latter family is absent in the Apyrenum Subchronozone. The Robuloididae Family is scarce $(0.25 \%)$ and its highest percentage is recorded in the Elegantulum Subchronozone, whereas one single specimen recorded in the middle part of the Hawskerense Subchronozone (sample 1SM.19) belongs to the Lagenidae Family (0.02\%).
The most abundant genera within the Lagenina Suborder correspond to Lenticulina, followed—far behind-by the genera Astacolus, Planularia, Paralingulina and Prodentalina. The most diverse genera are Nodosaria and Lenticulina. At the species level, Lenticulina toarcense constitutes the most abundant species, with 2690 specimens representing $55.37 \%$ of all those studied in the SMA Section; it presents relative frequencies greater than $30 \%$ in many of the assemblages, except in samples 1SM.57B, 1SM.57T and 1SM.109. Other abundant species in certain levels involve Astacolus chicheryi (7.14\%), with relative frequencies greater than $42 \%$ in the upper part of the Sublevisoni Subchronozone and the lower part of the Bifrons Subchronozone, Paralingulina tenera (3.36\%), which shows its highest relative abundance (14.40\%) at the base of the Hawskerense Subchronozone, and Marginulina prima (3.07\%), with relative frequencies greater than $8 \%$ in samples 1 SM.7 and 1SM.51 of the Apyrenum and Semicelatum subchronozones, respectively.

The Robertinina Suborder is recorded almost continuously from the lower part of the Apyrenum Subchronozone to the upper part of the Semicelatum Subchronozone; it presents relative abundances that do not exceed 3.62\% in most of the assemblages, except in sample 1SM.19, in which it represents $17 \%$ and in sample 1SM.57B, where it reaches $55.56 \%$. Nonetheless, it should be pointed out that the total number of foraminifera in the latter sample is very low. The foraminifera included in this suborder were grouped within the Ceratobuliminidae Family, but they could not be classified at the genus or species level due to the fact that the specimens were internal moulds.

The Textulariina Suborder is represented discontinuously from the upper part of the Hawskerense Subchronozone to the upper part of the Semicelatum Subchronozone; it presents relative frequencies that do not exceed $2.04 \%$, except in level 1SM.57T, where it reaches $84.06 \%$ of the specimens obtained. Two families are present: on the one hand, the Haplophragmoididae Family (1.19\%), with a single record in sample 1SM.57T (top of the Semicelatum Subchronozone) and represented by the taxa Haplophragmoides? sp. 1 and $H$. ? sp. 2 and, on the other hand, the Lituolidae Family (0.37\%), with Ammobaculites barrowensis, a species that reaches its maximum abundance at the base of the Paltum Subchronozone.

The Spirillinina Suborder, represented by the Spirillinidae Family, Spirillina infima species, appears in a discontinuous manner from the middle part of the Semicelatum Subchronozone to the upper part of the Elegantulum Subchronozone, with relative frequencies ranging from 0.29 to $11.11 \%$. Lastly, the foraminifera assigned to the Miliolina Suborder are scarce in the samples studied; we identified two specimens included in the Ophthalmidiidae Family, which were left in open 
nomenclature: Ophthalmidium sp. 1 in samples 1SM.15 (Hawskerense Subchronozone) and 1SM.51 (Semicelatum Subchronozone).

\section{Discussion}

The San Miguel de Aguayo Section features a range of advantages most notably related with a complete and well-exposed succession of materials that have granted all ammonites Chronozones and Subchronozones from the Upper Pliensbachian to the Middle Toarcian. Other sections are relevant such as Camino, close to Reinosa (Braga et al. 1985, 1988; Goy et al. 1994; Rosales et al. 2004), San Andrés (Goy et al. 1994; Gómez and Goy 2011) and Tudanca (Gómez and Goy 2011), but the SMA Section presents the most expanded profile, with no tectonic complexity or significant discontinuities. Moreover, in this section the foraminiferal events can be easily be calibrated with the ammonite biochronostratigraphy.

We provide a discussion of the key issues in relation to the ammonite chronostratigraphy and the palaeoecology, palaeobiogeography and biostratigraphy of the foraminifera. The consequences of the biotic extinction event of the Lower Toarcian for the ammonites and foraminifera of the San Miguel de Aguayo Section have also been addressed.

\subsection{Chronostratigraphic considerations}

The ammonite chronostratigraphic reference scale used for the Basque-Cantabrian Basin is almost equivalent to that established by Dommergues et al. (1997) for the Upper Pliensbachian (Spinatum Chronozone), by Elmi et al. (1997) for the Lower Toarcian of the NW European Province and by Page (2003) for the Submediterranean Province. The equivalencies and correlations among these ammonite charts can be verified in Osete et al. (2007), Gómez et al. (2008) and Gómez and Goy (2011).

The Upper Pliensbachian (Spinatum Chronozone) ammonite assemblages in the SMA Section are quite similar to those of the Camino Section in the Basque-Cantabrian Basin (Braga et al. 1985) and Rodiles Section in the Asturian Basin (Comas-Rengifo et al. 2016); they present a more expanded record and there are more levels with specimens than in the Southern Pyrenees (Fauré 2002). On the other hand, the Toarcian in SMA possesses a better ammonite record than Cillamayor, San Andrés, Camino and Tudanca sections of the Basque-Cantabrian Basin (Braga et al. 1988; Bernad 1992; Goy et al. 1994; Gómez and Goy 2011) or Pont-de-Suert and Sierras Marginales of the Southern Pyrenees (Fauré 2002).

In the SMA Section the Amaltheidae Family is relatively abundant in the Spinatum Chronozone, as occurs in other sections of the Basque-Cantabrian Basin (Braga et al. 1985, 1988 ) and in practically all the basins of the $\mathrm{N}$ of the Iberian Peninsula (Suárez Vega 1974; Fauré 2002; Comas-Rengifo and Goy 2010; Comas-Rengifo et al. 2016, Duarte et al. 2018a) although they are relatively scarce in the Southern Pyrenees (Fauré 2002). This group presents a broad geographic distribution in the NW European Province (e.g., Howarth 1958a, b; Dagis 1976; Comas-Rengifo 1982; Dommergues et al. 1997; Page 2003) although it is uncommon in the Mediterranean Province (Braga 1983; Braga et al. 1984). Some specimens of Pleuroceras cf. apyrenum have been identified together with Amaltheus cf. margaritatus, a species that persisted throughout most of the Apyrenum Subchronozone in the Basque-Cantabrian Basin as in other basins of the Subboreal and Submediterranean provinces (Howarth 1958a, b; Comas-Rengifo 1982; Elmi et al. 1997; Fauré 2002; Mouterde et al. 2007; Comas-Rengifo et al. 2016; Duarte et al. 2018a). Following the last record of Pleuroceras (Fig. 2), as in the rest of the Basque-Cantabrian Basin, in the SMA Section the Arieticeratinae (Canavaria and Tauromeniceras) persist in levels prior to the start of the Toarcian Stage (Comas-Rengifo et al. 2016). These genera, along with Emaciaticeras, which was not recorded until now in SMA Section, but rather in nearby areas like the Camino Section (Braga et al. 1985), are typical of the Mediterranean Province and of the southern part of the Submediterranean Province (Dubar and Mouterde 1978; Braga 1983; Comas-Rengifo 1982; Venturi and Ferri 2001; Macchioni and Meister 2003; Goy et al. 2006b; Comas-Rengifo et al. 2010a, b; Rocha et al. 2016; Duarte et al. 2018a, b). In the $\mathrm{N}$ of the Iberian Peninsula, the Arieticeratinae Subfamily is commonly found in the Lusitanian Basin (Mouterde 1967; Elmi 2006; Mouterde et al. 2007; Rocha et al. 2016) and in the Iberian Range (Comas-Rengifo 1982; Goy et al. 1998; ComasRengifo et al. 2010a, b); they are rarely found in the BasqueCantabrian Basin (Braga et al. 1985, 1988; Goy et al. 1994; Gómez and Goy 2011), the Asturian Basin (Comas-Rengifo and Goy 2010; Goy et al. 2010), or in the French-Spanish Pyrenees (Fauré 2002).

The Toarcian starts in the $\mathrm{N}$ of the Iberian Peninsula, and sporadically in Vendée (France), with the first record of Dactylioceras (Eodactylites) simplex, followed by other species of $D$. (Eodactylites), such as D. (E.) pseudocommune, $D$. (E.) mirabile or $D$. (E.) polymorphum. These species are typically Mediterranean or Submediterranean (Ferreti 1975; Goy et al. 1988, 2006b; Elmi et al. 1989, 2006; Jiménez and Rivas 1991; Cresta et al. 1995; Bécaud 2006; Bilotta et al. 2010; etc.) and they might be associated with Protogrammoceras (Paltarpites) of the $P$. ( $P$.) paltum group in the Iberian Range (Goy et al. 1988, 2010; Elmi et al. 1989), in the Cantabrian Basin (Goy et al. 1994, 2010; Gómez et al. 2008) and in the Lusitanian Basin (Rocha et al. 2016; Duarte et al. 2018a, b). This fact facilitates correlations with the basins in the north of the Submediterranean Province and with the 
Subboreal Province, where the index species of the Paltum Subchronozone is more common (Maubeuge and Rioult 1964; Gabilly 1976; Schlatter 1985; Howarth 1992a; Elmi et al. 1997; Bécaud 2006).

In the Semicelatum Subchronozone Dactylioceras (Orthodactylites) crosbeyi is a common species in the Basque-Cantabrian Basin and, in general, throughout the $\mathrm{N}$ of Iberia. D. (O.) tenuicostatum is rare and has not been cited in the Lusitanian Basin, and the species $D$. (O.) semicelatum presents a broad geographic distribution. This last species is abundant and in some cases persists until the base of the Serpentinum Chronozone, after the first record of E. elegantulum. This also occurs in the Exaratum Subchronozone of the Subboreal Province (Howarth 1978, 1992a, b; Page 2003). The presence of Orthildaites (O. douvillei) in the uppermost Serpentinum Chronozone enables the Subboreal and Submediterranean provinces to be correlated with areas of the Mediterranean Province such as the Betic Cordillera (Goy et al. 1988) and the Apennines (Cresta et al. 1995; Macchioni and Cecca 2002; Bilotta et al. 2010).

\subsection{Palaeoecological, palaeobiogeographic and biostratigraphic remarks based on the foraminifera}

The mechanisms of taphonomic alteration acting upon the studied foraminifera in the SMA Section indicate that the assemblages are autochthonous, as juvenile and adult specimens from most of the taxa are present in the samples; the effects of biostratinomic transport can therefore be considered to be quite insignificant, thus enabling palaeoecological and biostratigraphic inferences to be made. It should be pointed out that, due to the dissolution of the aragonitic shells, the specimens assigned to the Ceratobuliminidae Family could not be classified at the genus or species levels.

The Upper Pliensbachian and Toarcian sediments are included in a transgression-regression cycle in which the deepening trend culminates with the development of black shales (Quesada et al. 2005), the so-called Early Toarcian Oceanic Anoxic Event (ETOAE; see Gómez and Goy 2011, for a review). The low TOC values in the present study $(\leq 2 \%)$ cannot be consider as real black shales facies as has been pointed out by Gómez and Goy (2011) in other sections of the Basque-Cantabrian Basin. Thus, no record of any oceanic anoxic event can be considered to exist in the SMA Section. Unlike in the Pliensbachian of the Camino Section, where high TOC values $(<5 \%)$ are associated with a decrease in the foraminiferal abundance and taxonomic diversity (Herrero 1998), in the Pliensbachian-Toarcian transition in SMA and other sections of the BasqueCantabrian Basin (Camino Section, Herrero and Salazar Ramírez 2014; San Andrés Section, Salazar Ramírez and Herrero 2015), the changes in abundance and richness do not present a clear negative correlation with the TOC data. Both high and low richness values are recorded in samples enriched with organic matter. The trends in diversity cannot be explained only by fluctuations in organic matter; seawater temperature might also be highly relevant (for a discussion in this sense see Gómez and Goy 2011 and Salazar Ramírez and Herrero 2015).

The foraminiferal faunas studied are interpreted within the biogeographic framework proposed by Gordon (1970) for the Jurassic as constituting type A.1 assemblages, comprising over 1/5 of the specimens of Lagenina Suborder and involving the presence of small benthic agglutinated forms. Following this author, the type A faunas appear to be characteristic of the Jurassic boreal shelves of North America, the northern two-thirds of Europe and scattered points south of the Tethys Zone (e.g., Egypt and north of Somalia). According to the proposal by Basov and Kuznetsova (2000a, b; see Nikitenko 2008 for further details) the type A.1 assemblages are typical of the Atlantic Boreal Domain. Moreover, as indicated by Gordon (1970), these last assemblages are the most widespread in shelf areas, and biostratigraphic comparisons between different basins of the same domain would therefore be more reliable and would provide valuable palaeogeographical information.

Taxonomic and quantitative analysis of the foraminiferal assemblages highlights some aspects of palaeoecological interest. The Lagenina Suborder shows a highly continuous stratigraphic distribution, dominating the remaining suborders (Textulariina, Miliolina, Spirillinina and Robertinina), which represent a minority and exhibit a sporadic record; the Vaginulinidae Family and the Lenticulina genus are the most abundant. These features are common to the foraminiferal assemblages of coeval sections of the Basque-Cantabrian Basin (Herrero 1998; Herrero and Salazar Ramírez 2014; Salazar Ramírez and Herrero 2015) and of the Iberian Range (Herrero 1992, 1994, 2001, 2006, 2008, 2011). Another relevant aspect involves the acme of the Ceratobuliminidae Family in the middle part of the Hawskerense Subchronozone (sample 1SM.19). This peak in abundance is situated in deepening sequences in neighbouring areas (Salazar Ramírez and Herrero, 2015) and in the literature it has been associated with transgression events or deepwater environments (Brouwer 1969; Copestake and Johnson 1989; Hylton and Hart 2000). As stated by Copestake and Johnson (1989), under normal marine shelf conditions the Jurassic foraminiferal boreal faunas were dominated by nodosariids (=Lagenina Suborder), with lesser amounts of other benthic groups. Additionally, in the samples analysed in the present research, we also found fossil remains of other marine groups that inhabited environments under normal salinity; among these are crinoids, echinoids, brachiopods, belemnites and holothurids. 
The analysis of the stratigraphic distributions of the taxa identified in the Upper Pliensbachian-Middle Toarcian of the SMA Section reveals some similarities and differences in relation to those recorded in other contemporary sections of the Basque-Cantabrian Basin and of the Iberian Peninsula, specifically the Betic Cordillera, the Iberian Range, the Pyrenees and the Lusitanian Basin.

With regard to the extinction bioevent, several typically Pliensbachian species (Astacolus matutinus, Ichthyolaria sulcata, I. intumescens, Marginulina prima, M. cf. interrupta, M. cf. spinata, Mesodentalina cf. matutina, Planularia pulchra, Prodentalina terquemi, Paralingulina tenera and Saracenella sublaevis) were last recorded in different levels of the Paltum and Semicelatum subchronozones (Tenuicostatum Chronozone) in the SMA Section. However, some of them disappeared early in the Pliensbachian (mostly in the Margaritatus and Spinatum chronozones) in other sections of the Iberian Peninsula. Thus, in the Camino Section of the Basque-Cantabrian Basin, Ichthyolaria sulcata, Astacolus matutinus and Mesodentalina matutina present their last record in the Spinatum Chronozone, Hawskerense Subchronozone (Herrero 1998; Herrero and Salazar Ramírez 2014). In the Pyrenees, Planularia inaequistriata, $P$. pulchra and Astacolus speciosus disappear in the Margaritatus Chronozone, and A. matutinus is recorded for the last time in the Spinatum Chronozone (Nicollin et al. 1995; Nicollin and Fauré 1997). In the Betic Cordillera, Ichthyolaria sulcata presents its last record in the Margaritatus Chronozone, whereas Mesodentalina matutina disappears in the Spinatum Chronozone (Mira 1986). In the Lusitanian Basin (Portugal), Planularia pulchra and Prodentalina terquemi are found for the last time in the Lower Pliensbachian (Jamesoni and Ibex chronozones, respectively) and the last record of Planularia inaequistriata, Astacolus speciosus, Ichthyolaria sulcata, I. intumescens, Marginulina prima, Paralingulina tenera and Saracenella sublaevis takes place in the Spinatum Chronozone (Exton 1979). Moreover, the species Marginulina prima, Prodentalina terquemi and Saracenella sublaevis disappear in the Semicelatum Subchronozone both in SMA Section and in the Iberian Range (Herrero 1992). Importantly, some taxa can sometimes persist up to the Serpentinum Chronozone, Elegantulum Subchronozone (Lower Toarcian). This is the case of Ichthyolaria intumescens in the Ariño Section of the Iberian Range (Herrero 2011) and of Paralingulina tenera in Almonacid de la Cuba, Ariño, Calanda and Moneva sections of the Iberian Range (Herrero 1992, 2008, 2011 and unpublished data) and in the Pont-de-Suert, Camarasa and Ametlla sections in the Spanish Pyrenees (Nicollin et al. 1995).

The faunal turnover bioevent that takes place in the SMA Section, with the appearance of the genus Citharina in the Serpentinum Chronozone (lower part of the Elegantulum Subchronozone), is detected in some coeval sections. As a result, the species Citharina colliezi is first recorded in different levels of the Serpentinum Chronozone in the Basque-Cantabrian Basin (Herrero and Salazar Ramírez 2014; Salazar-Ramírez and Herrero 2015), the Iberian Range (Ruget 1982; Herrero 1992, 1994, 2001, 2008, 2011), the Betic Cordillera (Mira 1987), the Spanish Pyrenees (Nicollin et al. 1995; Nicollin and Fauré 1997) and the Lusitanian Basin (Exton 1979). Likewise, the species Citharina clathrata makes its first appearance in levels corresponding to the Serpentinum Chronozone. It is recorded for the first time in materials from the Elegantulum Subchronozone (Herrero and Salazar Ramírez 2014) and the Falciferum Subchronozone (Salazar Ramírez and Herrero 2015) in the BasqueCantabrian Basin. In the Iberian Range, this species appears in the Elegantulum Subchronozone (Herrero 2008) or the Falciferum Subchronozone (Barranco de las Alicantas and Rambla del Salto sections, see Herrero 1992, 1994, 2001); furthermore Mira (1986) cited it from the upper part of the Serpentinum Chronozone in the Betic Cordillera. Exton (1979) also found it for the first time in the Serpentinum Chronozone in Zambujal (Portugal).

As regards the species typical of the Pliensbachian-Toarcian transition, Eoguttulina palomerensis is recorded in the SMA Section from the Spinatum Chronozone (Hawskerense Subchronozone) to the Tenuicostatum Chronozone (Semicelatum Subchronozone). This species presents single or short records in other sections of the Basque-Cantabrian Basin (e.g., San Andrés Section, Salazar Ramírez and Herrero 2015), Iberian Range (Rambla del Salto Section, Herrero 1992, 2001) and of the Lusitanian Basin (e.g., Zambujal Section, Exton 1979), as well as a longer record from the Spinatum Chronozone (Apyrenum Subchronozone) to the Tenuicostatum Chronozone (Semicelatum Subchronozone) in the Iberian Range (Almonacid de la Cuba and Ariño sections, see Herrero 2008, 2011). Furthermore, the species Saracenella aragonensis mostly presents single records in the Tenuicostatum Chronozone in the Basque-Cantabrian Basin and the Iberian Range, although it has also been found in short stratigraphic intervals, from the Paltum Subchronozone to the Semicelatum Subchronozone in some sections of the Iberian Range (e.g., Barranco de las Alicantas Section, Herrero 1994). In the Pyrenees it has been recorded from the Tenuicostatum Chronozone to the Serpentinum Chronozone (Nicollin et al. 1995; Nicollin and Fauré 1997). Lastly, mention should be made of Planularia obonensis, an index species for the Lower Toarcian that has been recorded in other sections of the Basque-Cantabrian Basin (Herrero 1998; Herrero and Salazar Ramírez 2014; Salazar Ramírez and Herrero 2015) and in other Iberian basins (Ruget 1982, 1985; Herrero 1992, 1994, 2001, 2008, 2011; Nicollin et al. 1995), but which has not been identified in the SMA Section. 


\subsection{The biotic extinction event of the Lower Toarcian}

A critical biotic event, presumably associated with a noteworthy temperature rise, and which reaches its maximum in the upper part of the Semicelatum Subchronozone and at the base of the Elegantulum Subchronozone, and which affects the ammonites, can be observed in the SMA Section and in other sections of the Cantabrian Basin (Gómez and Goy 2000, 2011; Macchioni and Cecca 2002; Cecca and Macchioni 2004; Rosales et al. 2004; Gómez et al. 2008, among others). Other fossil groups are also affected to a greater or lesser degree: benthic invertebrates such as the brachiopods, which practically disappear from the Basque-Cantabrian Basin and from Asturias during the interval between the Serpentinum and Bifrons chronozones (García Joral and Goy 2009; García Joral et al. 2011), and the ostracods, 75\% of whose taxa progressively disappear within the Tenuicostatum Chronozone in the Iberian Range (Gómez and Arias 2010). Protists such as the calcareous nannoplankton are also affected by this biotic crisis in the Tenuicostatum Chronozone in the Basque-Cantabrian Basin (Tremolada et al. 2005) and in Asturias (Fraguas et al. 2012), with the extinction boundary situated between the Semicelatum Subchronozone and the Elegantulum Subchronozone.

Unlike other fossil groups, within the ammonites there is no complete disappearance of any of the families involved in the extinction event in the SMA Section. Both the Dactylioceratidae and the Hildoceratidae are recorded before the Tenuicostatum Chronozone and after the Serpentinum Chronozone (Elegantulum Subchronozone). Significant changes, however, can be observed in some of the subfamilies. Within the Hildoceratidae there is a complete extinction of the Protogrammoceratinae at the base of the Serpentinum Chronozone, as well as of some genera of Harpoceratinae throughout the Tenuicostatum Chronozone: Lioceratoides and Neolioceratoides at the base of the Semicelatum Subchronozone and Tiltoniceras in the uppermost part of the latter subchronozone.

Within the Dactylioceratidae, the first record of the Dactylioceratinae Subfamily takes place at the base of the Tenuicostatum Chronozone, coinciding with a regional transgressive episode following the disappearance of the Coeloderoceratinae Subfamily and of the Amaltheidae Family, and the virtual disappearance of the Arieticeratinae. The crisis apparently had minor effects, only involving some subgeneric and species taxa. The Dactylioceras (Eodactylites) become extinguished at the end of the Paltum Subchronozone, and the Dactylioceras (Orthodactylites) suffer a significant decline as from the base of the Elegantulum Subchronozone. The SMA Section witnesses the disappearance of the species $D$. (O.) semicelatum and $D$. (O.) ernsti, with only $D$. (O.) semiannulatum and $D$. (O.) andaluciensis (see Fig. 2) persisting in this subchronozone.
Following this extinction event, the ammonites undergo a notable renovation up to the end of the interval studied. The Hildoceratinae Subfamily (Hildaites, Orthildaites, Hildoceras) appears, becoming dominant in the Bifrons Subchronozone, and the Harpoceratinae Subfamily, which is represented by genera different from those recorded prior to the biotic extinction event, shows consistent persistence (Eleganticeras, Harpoceras, Cleviceras, Polyplectus). In addition, the occasional presence of Dactylioceratinae is reported (Dactylioceras, Nodicoeliceras, Peronoceras) which, as in the rest of the Basque-Cantabrian Basin, becomes progressively renovated throughout the Serpentinum and Bifrons chronozones (Goy et al. 1994).

As has previously been stated, the biotic crisis in the Lower Toarcian also affects the foraminifera, through stepwise extinction of species typical of the Lower Jurassic throughout the Hawskerense Subchronozone (Spinatum Chronozone) and the Paltum and Semicelatum subchronozones (Tenuicostatum Chronozone), both in the SMA Section and in other sections of the Basque-Cantabrian Basin (Herrero and Salazar Ramírez 2014; Salazar Ramírez and Herrero 2015) and of the Iberian Range (Herrero 2008, 2011, 2017). The maximum extinction rate appears to be situated in the Semicelatum Subchronozone in SMA, as also occurs in other sections of the aforementioned basins. This extinction does not affect suprageneric taxonomic categories, and the presence of the same subfamilies, families, superfamilies and suborders of foraminifera has been reported throughout the Toarcian (based on data from Herrero and Canales 1997; Canales and Herrero 2000) and at the upper stages (based on data from Canales 2001; Gräfe 2005). Nonetheless, unlike the ammonites and other groups of invertebrates, the genera are not affected either. Thus, the biotic extinction event in the Lower Toarcian in relation to foraminifera only involves the species level, although with different degrees of intensity in the different genera.

Of the 69 taxa recorded in the SMA Section, 12 (17.4\%) typical Lower Jurassic species become extinct before reaching the Serpentinum Chronozone. The Robuloidoidea and Nodosarioidea superfamilies, both of the Lagenina Suborder, are affected by the extinction. Within the Nodosarioidea Superfamily, Vaginulinidae Family, seven species become extinct, affecting only two of its main subfamilies, Marginulininae (four species) and Vaginulininae (three species). The Lenticulininae Subfamily (Vaginulinidae) and the Nodosariidae, Lagenidae and Polymorphinidae families are not affected. Within the Robuloidoidea, only in the Ichthyolariidae Family are extinctions seen to occur, with the disappearance of 5 of its species; although the Robuloididae Family is not affected. The genera Ichthyolaria, Marginulina and Astacolus exhibit the highest number of species extinguished from the Hawskerense Subchronozone to the Semicelatum Subchronozone. 
As from the Elegantulum Subchronozone, the faunal turnover involves the Ichthyolariidae, Robuloididae, Nodosariidae and Vaginulinidae families, with a total of 10 species appearing for the first time. The most significant renovation and diversification event occurs within the Vaginulininae Subfamily, in which the genus Citharina is recorded for the first time, with four of its species.

\section{Conclusions}

In the present paper we analysed the ammonites and foraminifera of the SMA Section for the interval ranging from the Upper Pliensbachian (Spinatum Chronozone, Apyrenum Subchronozone) to the Middle Toarcian (Bifrons Chronozone, Bifrons Subchronozone pars). The specimens of both groups present a medium-to-good degree of conservation, and we obtained good successions of complete, representative and autochthonous assemblages. The biotic extinction event of the Lower Toarcian can be recognised in the two fossil groups studied herein. In both cases the extinction mainly affects the species level, and in the case of the ammonites, some genera are also impacted. However, neither the ammonite nor the foraminifer families or any higher taxonomic categories are affected.

The ammonites in the SMA Section and in others of the Basque-Cantabrian Basin, such as the Camino Section close to Reinosa, San Andrés next to Puerto de Pozazal and Tudanca, can be considered as being typical of the Submediterranean Province. Nonetheless, they present clear similarities with the basins of the Subboreal Province due to the significant record of $D$. (Orthodactylites) in the Tenuicostatum Chronozone (Semicelatum Subchronozone), Eleganticeras and Cleviceras in the Serpentinum Chronozone (Elegantulum Subchronozone), and Harpoceras (H. serpentinum- $H$. falciferum-H.subplanatum) in the Serpentinum and Bifrons chronozones. The taxa typical of the Mediterranean Province in the SMA Section are relatively few, and their record is limited to the uppermost Spinatum Chronozone, which contains Canavaria and Tauromeniceras, and to the lower part of the Tenuicostatum Chronozone, with several species of D. (Eodactylites), Neolioceratoides and scarce Protogrammoceras. Other elements of correlation with the main basins of the above mentioned provinces involve Pleuroceras $(P$. spinatum, $P$. hawskerense), followed by Canavaria sp. and Tauromeniceras sp., which indicate the Late Pliensbachian; Orthildaites (O. douvillei), recorded in the Late Lower Toarcian, and the succession of Hildoceras (H. sublevisoni-H. lusitanicum- $H$. apertum- $H$. bifrons), coinciding with the transgressive part of the T5-R5 cycle defined in the BasqueCantabrian Basin.

The foraminifera correspond to faunas typical of the Atlantic Boreal Domain in which Lagenina is the best represented suborder, although the Robertinina, Textulariina, Spirillinina and Miliolina suborders are also present albeit as minority groups. Of the total number of taxa recognised, 62 are included in the Lagenina Suborder, three in the Textulariina Suborder, one in the Miliolina Suborder, one in the Spirillinina Suborder and one family in the Robertinina Suborder. The best represented genus in terms of number of specimens is Lenticulina and the most diverse one is Nodosaria, with nine recognised taxa. The species Lenticulina toarcense is the most abundant, presenting an almost continuous record throughout the stratigraphic interval considered. We can highlight two main bioevents, on the one hand, the stepwise extinction of species typical of the Pliensbachian, which is more intense in the Semicelatum Subchronozone (Tenuicostatum Chronozone) and on the other, the faunal turnover and diversification event recorded as from the Elegantulum Subchronozone (Serpentinum Chronozone). Comparison with other contemporary sections of the Iberian Peninsula has enabled us to corroborate the similarity and significance of these two bioevents involving the disappearance of species typical of the Lower Jurassic, which were subsequently replaced by Middle Jurassic faunas.

Acknowledgements The authors would like to thank Prof. María José Comas for the critical review of part of the manuscript and for her highly useful comments on the ammonites of the Late Pliensbachian. The authors also wish to thank Dr. Ana Vicente Montaña from the Centro Nacional de Microscopía Electrónica (Complutense University of Madrid, UCM, Spain) for providing the photographs of the foraminifera. Our thanks are also due to Mr. Carlos Alonso Recio (UCM) for the photographs of the ammonite specimens and the digital processing of all images. We would also like to thank Mr. Cormac de Brun for the English translation of the manuscript. The comments and suggestions of the associate editor Prof. Kai-Uwe Gräfe and anonymous referees were very useful with regard to improving the manuscript. This research was funded by the Project CGL2015-66604-R MINECO (Ministerio de Economía y Empresa- Spain) and by the UCM Work Group $n^{\circ}$ 910431. Roselis W. Salazar Ramírez is also grateful for the financial support provided by the SYNTHESYS grant scheme to undertake a research visit (GB-TAF-4912) at the NHM (London). Additionally, the present study is framed within the International Geoscience Programme (IGCP), Project $n^{\circ} 655$ (UNESCO-IUGS).

\section{References}

Assens, J. (1971). Excursión a las secciones de Montoria y Quintanaopio. Cuadernos de Geología Ibérica, 2, 631-636.

Basov, V. A., \& Kuznetsova, K. I. (2000a). Paleogeographic aspects in research of Jurassic foraminifers. In Problems of Stratigraphy and Paleontology. St. Petersburg: SPbU. (in Russian).

Basov, V. A., \& Kuznetsova, K. I. (2000b). Dynamics of diversity and evolutionary trends of Jurassic foraminifers. Stratigraphy and Geological Correlation, 8(6), 593-607.

Bécaud, M. (2006). Les Harpoceratinae, Hildoceratinae et Paroniceratinae du Toarcien de la Vendée et des Deux-Sèvres (France). Documents des Laboratoires de Géologie de Lyon, 162, 1-245 
Bernad, J. (1992). El Toarciense en la región de Cillamayor-Salinas de Pisuerga (Cuenca Vasco-Cantábrica). Paleontología (Ammonoideos) y Bioestratigrafía. Madrid: M. Sc. Thesis, Universidad Complutense (unpublished).

Bilotta, M., Venturi, F., \& Sassaroli, S. (2010). Ammonite faunas, OAE and the Pliensbachian-Toarcian boundary (Early Jurassic) in the Apennines. Lethaia, 43, 357-380.

Braga, J. C. (1983). Ammonites del Domeriense de la Zona Subbética (Cordilleras Béticas, Sur de España). Tesis Doctoral. Granada: Universidad de Granada.

Braga, J. C., Comas-Rengifo, M. J., Goy, A., \& Rivas, P. (1984). The Pliensbachian of Spain: Ammonite successions, boundaries and correlation. In O. Michelsen \& A. Zeiss (Eds.), First International Symposium on Jurassic Stratigraphy (pp. 160-176). Copenhagen: Danish Geological Survey.

Braga, J. C., Comas-Rengifo, M. J., Goy, A., \& Rivas, P. (1985). Le Pliensbachien dans le Chaîne Cantabrique orientale entre Castillo Pedroso et Reinosa (Santander, Espagne). Les Cahiers de l'Institut Catholique de Lyon, 14, 69-84.

Braga, J. C., Comas-Rengifo, M. J., Goy, A., Rivas, P., \& Yébenes, A. (1988). El Lías inferior y medio en la zona central de la Cuenca Vasco-Cantábrica (Camino, Santander). Ciencias de la Tierra, Geología, 11, 17-46.

Brouwer, J. (1969). Foraminiferal assemblages from the Lias of NorthWestern Europe. Verhandelingen der Koninklijke Nederlandse Akademie van Wetenschappen, Afdeling Natuurkunde, 25(4), $1-64$.

Canales, M. L. (2001). Los Foraminíferos del Aaleniense (Jurásico Medio) en la Cuenca Vasco-Cantábrica (N de España). Revista Española de Micropaleontología, 33(3), 253-438.

Canales, M. L., \& Herrero, C. (2000). Asociaciones de foraminíferos del Toarciense superior y Aaleniense en la sección de Moyuela (Zaragoza, España). Revista Española de Micropaleontología, 32(3), 301-317.

Cecca, F., \& Macchioni, F. (2004). The two Early Toarcian (Early Jurassic) extinction events in ammonoids. Lethaia, 37, 35-56.

Comas-Rengifo, M. J. (1982). El Pliensbachiense de la Cordillera Ibérica. Tesis Doctoral. Madrid: Universidad Complutense, 19/85, 1-591 (published in 1985).

Comas-Rengifo, M. J., \& Goy, A. (2010). Caracterización biocronoestratigráfica del Sinemuriense Superior y el Pliensbachiense entre los afloramientos de la Playa Vega y Lastres (Asturias). In J. C. García-Ramos (Coord.), Las sucesiones margo-calcáreas marinas del Jurásico Inferior y las series fluviales del Jurásico Superior. Acantilados de la Playa de Vega (Ribadesella), V Congreso del Jurásico de España (pp. 10-18). Colunga: Museo del Jurásico de Asturias (MUJA)

Comas-Rengifo, M. J., Arias, C., Gómez, J. J., Goy, A., Herrero, C., Osete, M. L., \& Palencia, A. (2010a). A complementary section for the proposed Toarcian (Lower Jurassic) global stratotype: The Almonacid de la Cuba section (Spain). Stratigraphy and Geological Correlation, 18(2), 133-152.

Comas-Rengifo, M. J., Gómez, J. J., Goy, A., Osete, M. L., \& Palencia, A. (2010b). The base of the Toarcian (Early Jurassic) in the Almonacid de la Cuba section (Spain). Ammonite biostratigraphy, magnetostratigraphy and isotope stratigraphy. Episodes, 33(1), 15-22.

Comas-Rengifo, M. J., Duarte, L. V., Félix, F. F., Goy, A., Paredes, R., \& Silva, R. (2016). Amaltheidae e Hildoceratidae (Ammonitina) del Pliensbachiense superior (Cronozona Spinatum) en las cuencas septentrionales de la Península Ibérica. Actas de las XXXII Jornadas de la SEP. Cuadernos del Museo Geominero, $20,47-52$.

Copestake, P., \& Johnson, B. (1989). The Hettangian to Toarcian. In D. G. Jenkins \& J. W. Murray (Eds.), A Stratigraphical Atlas of
Fossil Foraminifera (2nd ed., pp. 129-188). Chichester: Ellis Horwood Limited.

Cresta, S., Basilici, G., Bussoletti, A., Comas, M. J., Elmi, S., Fernández-López, S., Ferreti, A., Goy, A., Henriques, M. H., Kalin, O., Jiménez, A., Martínez, G., Sandoval, J., Ureta, S., \& Venturi, F. (1995). Relazione sul workshop "paleontología y biostratigrafía dei sedimenti ammonitifere Toarciano-Bajociano in succesioni di alto morfostructurale dell'Appennino umbro-marchigiano: 1'area di Monte Nerone. Correlazioni con altre regioni della Tetide occidentale" (Piobbico, 2-14 Agosto 1993). Bolletino di Servizio Geologico d'Italia, 112, 1-12.

Dagis, A. A. (1976). Late Pliensbachian ammonites (Amaltheidae) of northern Siberia. Trudi Instituta Geologii i Geofizika, Novosivirsk, 309, 1-79.

Dahm, H. (1965). Stratigraphie und Paläogeographie im Kantabrischen Jura (Spanien). Beihefte zum Geologischen Jahrbuch, 44, 13-54.

Dommergues, J. L., Meister, C., \& Mouterde, R. (1997). Pliensbachian. In: E. Cariou and P. Hantzpergue (Eds.), Biostratigraphie $d u$ Jurassique ouest-européen et méditerranéen. Bulletin du Centre des Recherche Exploration Production Elf Aquitaine, 17, 15-23.

Duarte, L. V., Comas-Rengifo, M. J., Hesselbo, S., Mattioli, E., Suan, G., (coordinators), Baker, S., Cabral, M. C., Correia, V., García Joral, F., Goy, A., Reolid, M., Rita, P., Félix, F., Paredes, R., Pittet, B., \& Rocha, R. B. (2018a). The TOAE at Peniche. An exercise in integrated stratigraphy. In 2nd International Workshop on the Toarcian Oceanic Anoxic Event, Coimbra. The TOAE in the Western Iberian Margin and its context within the Lower Jurassic evolution of the Lusitanian Basin. Field Trip Guidebook (Stop 1.3, pp. 33-54). Coimbra.

Duarte, L. V., Comas-Rengifo, M. J., García Joral, F., Goy, A., MíguezSalas, O., \& Rodríguez-Tovar, F. J. (2018b). Sedimentological and macroinvertebrate record across the Lower Toarcian in the Rabaçal area. In 2nd International Workshop on the Toarcian Oceanic Anoxic Event, Coimbra. The TOAE in the Western Iberian Margin and its context within the Lower Jurassic evolution of the Lusitanian Basin. Field Trip Guidebook (Stop 2.2, pp. 71-82). Coimbra.

Dubar, G., \& Mouterde, R. (1978). Les formations à ammonites du Lias moyen dans le Haut Atlas de Midelt et du Tadla. Notes et Mémoires du Service géologique du Maroc, 274, 1-112.

Elmi, S. (2006). Pliensbachian/Toarcian boundary: the proposed GSSP of Peniche (Portugal). Volumina Jurassica, 4, 5-16.

Elmi, S., Atrops, F., \& Mangold, C. (1974). Les zones d'ammonites du Domérien-Callovien de l'Algérie occidentale. Première partie: Domérien-Toarcien. Documents des Laboratoires de Géologie de la Faculté des Sciences de Lyon, 61, 1-83.

Elmi, S., Goy, A., Mouterde, R., Rivas, P., \& Rocha, R. (1989). Correlaciones bioestratigráficas en el Toarciense de la Península Ibérica. Cuadernos de Geología Ibérica, 13, 265-277.

Elmi, S., Marok, A., Sebane, A., \& Alméras, Y. (2006). Importance of the Mellala section (Traras Mountains, NW Algeria) for the correlations of the Pliensbachian/Toarcian boundary. Volumina Jurassica, 4, 158-160.

Elmi, S., Rocha, R. B., Duarte, L. V., Mouterde, R., Cabral, M. C., Comas-Rengifo, M. J., Gómez, J. J., Goy, A., Hesselbo, S. P., Jenkyns, H. C., Littler, K., Mailliot, S., Mattioli, E., Oliveira, L. C. V., Osete, M. L., Perilli, N., Pinto, S., Pittet, B., Ruget, C., \& Suan, G. (2010). Formal proposal for the Global Boundary Stratotype Section and Point (GSSP) of the Toarcian Stage, at the base of the Polymorphum Zone in the Peniche Section (Portugal). In Société Géologique de France (Ed.), Réunion Spécialisée de la S.G.F. en hommage à Serge Elmi, Peuplements et environnements jurassiques (pp. 22-24). Lyon (France): Université de Lyon.

Elmi, S., Rulleau, L., Gabilly, J., \& Mouterde, R. (1997). Toarcien. In E. Cariou \& P. Hantzpergue (Eds.), Biostratigraphie du 
Jurassique ouest-européen et méditerranéen (17, pp. 25-36). Pau: Bulletin du Centre des Recherche Exploration Production Elf Aquitaine.

Exton, J. (1979). Pliensbachian and Toarcian microfauna of Zambujal, Portugal: Systematic paleontology. Carleton University, Department of Geology, Geological Paper, 79-1, 1-103.

Fauré, P. (2002). Le Lias des Pyrénées. Strata, Série II, 39, 1-761.

Ferreti, A. (1970). Il limite Domeriano-Toarciano nei gruppi montuosi del Nerone e del Catria (Appennino Marchigiano). Rivista Italiana di Paleontologia i Stratigrafia, 76(3), 445-462.

Ferreti, A. (1972). Ricerche biostratigrafiche sul Domeriano nel gruppo montuoso del Nerone e del Catria (Appennino marchigliano). Rivista Italiana di Paleontologia e Stratigrafia, 78(1), 93-130.

Ferreti, A. (1975). Ricerche biostratigrafiche sul Sinemuriano-Pliensbachiano nella gola del F. Bosso (Appennino marchigliano). Rivista Italiana di Paleontologia e Stratigrafia, 81(2), 161-194.

Fraguas, A. R., Comas-Rengifo, M. J., Gómez, J. J., \& Goy, A. (2012). The calcareous nannofossil crisis in Northern Spain (Asturias province) linked to the Early Toarcian warming-driven mass extinction. Marine Micropaleontology, 94-95, 58-71.

Gabilly, J. (1976). Le Toarcien à Thouars et dans le centre-ouest de la France. Les Stratotypes français, 3, 1-217.

García Joral, F., \& Goy, A. (2009). Toarcian (Lower Jurassic) brachiopods in Asturias (Northern Spain): Stratigraphic distribution, critical events and palaeobiogeography. Geobios, 42(3), 255-264.

García Joral, F., Gómez, J. J., \& Goy, A. (2011). Mass extinction and recovery of the Early Toarcian (Early Jurassic) brachiopods linked to climate change in Northern and Central Spain. Palaeogeography, Palaeoclimatology, Palaeoecology, 302, 367-380.

Gómez, J. J., \& Arias, C. (2010). Rapid warming and ostracods mass extinction at the Lower Toarcian (Jurassic) of central Spain. Marine Micropaleontology, 74, 119-135.

Gómez, J. J., \& Goy, A. (2000). Definition and organization of limestone-marl cycles in the Toarcian of the Northern and East-Central part of the Iberian Subplate (Spain). GeoResearch Forum, $6,301-310$

Gómez, J. J., \& Goy, A. (2005). Late Triassic and Early Jurassic palaeogeographic evolution and depositional cycles of the Western Tethys Iberian platform system (Eastern Spain). Palaeogeography, Palaeoclimatology, Palaeoecology, 222, 77-94.

Gómez, J. J., \& Goy, A. (2011). Warming-driven mass extinction in the Early Toarcian (Early Jurassic) of northern and central Spain. Correlation with other time-equivalent European sections. Palaeogeography, Palaeoclimatology, Palaeoecology, 306, 176-195.

Gómez, J. J., Goy, A., \& Canales, M. L. (2008). Seawater temperature and carbon isotope variations in belemnites linked to mass extinction during the Toarcian (Early Jurassic) in Central and Northern Spain. Comparison with other European sections. Palaeogeography, Palaeoclimatology, Palaeoecology, 258, 28-58.

Gordon, W. A. (1970). Biogeography of Jurassic foraminifera. Bulletin of the Geological Society of America, 81, 1689-1704.

Goy, A., Comas-Rengifo, M. J., Arias, C. F., García Joral, F., Gómez, J. J., Herrero, C., Martínez, G., \& Rodrigo, A. (1998). El tránsito Pliensbachiense/Toarciense en el Sector Central de la Rama Aragonesa de la Cordillera Ibérica (España). Les Cahiers de l'Institut Catholique de Lyon, 9, 17-19.

Goy, A., Martínez, G., \& Ureta, S. (2006a). Ammonoidea Toarcian biohorizons in the Basque-Cantabrian Basin (N Spain): a correlation between the Iberian Range and the Mediterranean Province Standard Scale. Volumina Jurassica, 4, 166-167.

Goy, A., Comas-Rengifo, M. J., Arias, C. F., Gómez, J. J., González, J. A., Herrero, C., Palencia, A., Perilli, N., \& Rodrigo, A. (2006b). The Pliensbachian-Toarcian boundary in the Almonacid de la
Cuba section (Iberian Range. Spain). Volumina Jurassica, 4, 164-166.

Goy, A., Comas-Rengifo, M. J., Gómez, J. J., Herrero, C., Suárez-Vega, L. C., \& Ureta, S. (2010). Biohorizontes de ammonoideos del Toarciense en Asturias. In J. J. Ruiz, L. Omeñaca, Piñuela y J. C. \& García-Ramos (Eds.), Comunicaciones del V Congreso del Jurásico de España (pp. 94-102). Colunga: Museo del Jurásico de Asturias (MUJA).

Goy, A., Jiménez, A., Martínez, G., \& Rivas, P. (1988). Difficulties in correlating the Toarcian ammonite succession of the Iberian and Betic cordilleras. In R. B. Rocha, and A. F. Ç. Soares (Eds.), Second International Symposium on Jurassic Stratigraphy (pp. 155-178). Lisboa.

Goy, A., Martínez, G., \& Ureta, S. (1994). El Toarciense en la región de Pozazal-Reinosa (Cordillera Cantábrica, España). Coloquios de Paleontología, 46, 93-127.

Gräfe, K. U. (2005). Benthic foraminifers and palaeoenvironment in the Lower and Middle Jurassic of the Western Basque-Cantabrian Basin (Northern Spain). Journal of Iberian Geology, 31(2), 217-233.

Guex, J. (1973). Aperçu biostratigraphique sur le Toarcien inférieur du Moyen-Atlas marrocain et discussion sur la zonation de ce sous-étage dans les séries méditerranéennes. Eclogae Geologicae Helvetiae, 66(3), 493-522.

Herrero, C. (1992). Los foraminíferos del Toarciense inferior de la Cordillera Ibérica. Colección Tesis Doctorales 87/93, Universidad Complutense de Madrid, 1-523 (published in 1993).

Herrero, C. (1994). Lower Toarcian Foraminifera from the Northern Sector of the Iberian Range (Spain). Geobios, M.S., 17, 287-295.

Herrero, C. (1998). Foraminíferos del Pliensbachiense en la Sección de Camino (Cuenca Vasco-Cantábrica, España). Cuadernos de Geología Ibérica, 24, 121-139.

Herrero, C. (2001). Foraminíferos del Toarciense en la Rambla del Salto (Sierra Palomera, Teruel, España): Distribución estratigráfica y principales eventos. Revista Española de Micropaleontología, 33(1), 79-89.

Herrero, C. (2006). Sucesión de asociaciones de foraminíferos en el tránsito Pliensbachiense-Toarciense en Almonacid de la Cuba (Zaragoza, España). Revista Española de Micropaleontología, 38(2-3), 339-354.

Herrero, C. (2008). Foraminiferal events in the Pliensbachian-Toarcian transition at Almonacid de la Cuba (Zaragoza, Spain), the complementary reference section of the proposed Toarcian GSSP. Neues Jahrbuch für Geologie und PaläontologieAbhandlungen, 250(2), 233-255.

Herrero, C. (2011). Foraminíferos del tránsito Pliensbachiense-Toarciense en la Sección de Ariño (Teruel, España). Revista Española de Micropaleontología, 43(1-2), 1-18.

Herrero, C. (2017). Early Toarcian foraminiferal events in the Central Sector of the Iberian Range (Spain) where neither black shales nor foraminifera mass extinction are recorded. In M. Reolid (Ed.), International Workshop on the Toarcian Oceanic Anoxic Event (pp. 69-71). Jaén: IGCP-655 (IUGS-UNESCO), 3 Impresores Sur, S.L.

Herrero, C., \& Canales, M. L. (1997). Diversidad en los foraminíferos del tránsito Toarciense/Aaleniense en la sección de Fuentelsaz. Revista Española de Paleontología, 12, 233-242.

Herrero, C., \& Canales, M. L. (2002). Taphonomic processes in selected Lower and Middle Jurassic foraminifera from the Iberian Range and Basque-Cantabrian Basin (Spain). Journal of Foraminiferal Research, 32(1), 22-42.

Herrero, C., \& Salazar Ramírez, R. W. (2014). Upper PliensbachianMiddle Toarcian Foraminiferal assemblages in the Camino Section (Basque-Cantabrian Basin, Spain). In R. Rocha et al. (Eds.), STRATI 2013 (pp. 1099-1103). Cham: Springer International Publishing. 
Howarth, M. K. (1958a). A Monograph of the Liassic ammonites of the family Amaltheidae in Britain. Part I. Monograph of the Palaeontographical Society of London, 111(480), i-xiv, 1-26, (1957).

Howarth, M. K. (1958b). A Monograph of the Liassic ammonites of the family Amaltheidae in Britain. Part I. Monograph of the Palaeontographical Society of London, 111(484), xv-xxvii, 27-53, (1958).

Howarth, M. K. (1978). The stratigraphy and ammonite fauna of the Upper Lias of Northamptonshire. Bulletin of the British Museum of Natural History, 29(3), 235-288.

Howarth, M. K. (1992a). The ammonite family Hildoceratidae in the Lower Jurassic of Britain. Part I. Monograph of the Palaeontographical Society of London, 145(586), 1-106.

Howarth, M. K. (1992b). The ammonite family Hildoceratidae in the Lower Jurassic of Britain. Part II. Monograph of the Palaeontographical Society of London, 146(590), 107-200.

Hylton, M. D., \& Hart, M. B. (2000). Benthic foraminiferal response to Pliensbachian-Toarcian (Lower Jurassic) sea-level change and oceanic anoxia in NW Europe. GeoResearch Forum, 6, 455-462.

Jiménez, A., \& Rivas, P. (1981). El Jurásico de las Zonas Externas de las Cordilleras Béticas. 3, Zona Subbética. 3.4, el Toarciense. Cuadernos de Geología de la Universidad de Granada, 10, 397-411.

Jiménez, A., \& Rivas, P. (1991). Los Dactylioceratidae del Toarciense inferior y medio de las Cordilleras Béticas, España. Boletín de la Real Sociedad Española de Historia Natural, 86, 149-203.

Loeblich, A. R., \& Tappan, H. (1988). Foraminiferal Genera and their classification. New York: Van Nostrand Reinhold Company.

Macchioni, F., \& Cecca, F. (2002). Biodiversity and biogeography of middle-late liassic ammonoids: implications for the Early Toarcian mass extinction. Geobios, M.S., 24, 165-175.

Macchioni, F., \& Meister, C. (2003). Ammonite biostratigraphy of some Mediterranean sections. 2. The succession of the Gola de F. Burano (Umbria-Machigiano Basin, Apennine), a reference section for Tethyan domain. Revue de Paléobiologie, 22(1), 363-420.

Maubeuge, P. L., \& Rioult, M. (1964). Presence de Paltarpites dans le Lias du Grand Duché de Luxembourg. Archives Institut GrandDucal de Luxembourg, 30, 107-113.

Mira, F. J. (1986). Foraminíferos del Lías margoso de las Cordilleras Béticas. Zona Subbética. Tesis Doctoral. Granada: Universidad de Granada (unpublished).

Mira, F. J. (1987). El género Citharina en el Lías de la Zona Subbética. Revista Española de Micropaleontología, 19(1), 151-159.

Mouterde, R. (1967). Le Lias de Portugal. Vue d'ensemble et división en zones. Comunicações dos Serviços Geológicos de Portugal, $52,209-226$.

Mouterde, R., Dommergues, J. L., Meister, C., \& Rocha, R. B. (2007). Atlas des fossiles caractéristiques du Lias portugais III a) Domérien (Ammonites). Ciências da Terra, 16, 67-111.

Nicollin, J. P., \& Fauré, P. (1997). Évolution des populations de foraminifères au cours du Lias moyen et supérieur dans quelques régions des Pyrénées. Les Cahiers de l'Université Catholique de Lyon, 10, 47-52.

Nicollin, J. P., Fauré, P., \& Ruget, C. (1995). Le Toarcien inférieur, période charnière dans l'évolution des Nodosariidés (Foraminifères): L'exemple des Pyrénées méridionales du HautAragon. Geobios, M. S., 18, 347-356.

Nikitenko, B. L. (2008). The Early Jurassic to Aalenian Paleobiogeography of the Arctic Realm: Implication of microbenthos (Foraminifers and Ostracodes). Stratigraphy and Geological Correlation, 16(1), 59-80.

Osete, M. L., Gialanella, P. R., Gómez, J. J., Villalaín, J. J., Goy, A., \& Heller, F. (2007). Magnetostratigraphy of Early-Middle Toarcian expanded sections from the Iberian Range (central Spain). Earth and Planetary Science Letters, 259, 319-332.

Page, K. (2003). The Lower Jurassic of Europe: its subdivision and correlation. Geological Survey of Denmark and Greenland Bulletin, 1, 23-59.

Parisi, G., Baldanza, A., Benedetti, L., Mattioli, E., Venturi, F., \& Cresta, S. (1998). Toarcian stratigraphy of the Colle d'Orlando section (Umbria, Central Italy, Northern Apennine). Bolletino della Società Paleontologica Italiana, 37(1), 3-39.

Perilli, N., \& Comas-Rengifo, M. J. (2002). Calibration of Pliensbachian calcareous nannofossil events in two ammonitecontrolled sections from Northern Spain (Basque-Cantabrian Area). Rivista Italiana di Paleontologia e Estratigrafia, 108(1), 133-152.

Perilli, N., Comas-Rengifo, M. J., \& Goy, A. (2004). Calibration of the Pliensbachian-Toarcian calcareous nannofossil zone boundaries based on Ammonites (Basque-Cantabrian Area, Spain). Rivista Italiana di Paleontologia e Estratigrafia, 110(1), 97-107.

Portero, J. M., del Olmo, P., Carreras, F. J., Aguilar, M. J., \& Ramírez del Pozo, J. (1978). Memoria de la Hoja no. 83 (Reinosa) y del Mapa Geológico Nacional 1:50.000, Instituto Geológico y Minero de España.

Quesada, S., \& Robles, S. (1995). Distribution of Organic facies in the Liassic Carbonate Ramps of the Western Basque-Cantabrian Basin (Northern Spain). In C. C. Dorronsoro (Ed.), Field trip guidebook, 17th International Meeting on Organic Geochemistry (pp. 1-36). San Sebastian: Asociación Ibérica de Geoquímica Orgánica y Ambiental.

Quesada, S., Robles, S., \& Rosales, I. (2005). Depositional architecture and transgressive-regressive cycles within Liassic backstepping carbonate ramps in the Basque-Cantabrian basin, northern Spain. Journal of the Geological Society of London, 162, 531-548.

Ramírez del Pozo, J. (1971a). Bioestratigrafía y microfacies del Jurásico y Cretácico del Norte de España (Región Cantábrica). Memorias Instituto Geológico y Minero de España, 78, 1-357.

Ramírez del Pozo, J. (1971b). Algunas observaciones sobre el Jurásico de Álava, Burgos y Santander. Cuadernos de Geología Ibérica, 2, 491-508.

Rivas, P. (1972). Estudio paleontológico estratigráfico del Lías en el sector Central de las Cordilleras Béticas. Tesis Doctoral. Granada: Universidad de Granada (unpublished). Summary 29, 77 pp.

Robles, S., Pujalte, V., \& Valles, J. C. (1988). Sistemas sedimentarios del Jurásico de la parte occidental de la Cuenca Vasco-Cantábrica. Ciencias de la Tierra, Geología, 11, 1-15.

Robles, S., Quesada, S., Rosales, I., Aurell, M., \& García-Ramos, J. C. (2004). El Jurásico marino de la Cordillera Cantábrica. In J. A. Vera (Ed.), Geología de España (pp. 279-285). Madrid: Sociedad Geológica de España-Instituto Geológico y Minero de España.

Robles, S., Quesada, S., Rosales, I., Aurell, M., Meléndez, G., \& Bádenas, B. (2002). 11. Jurassic. Basque-Cantabrian basin. In W. Gibbons \& T. Moreno (Eds.), The Geology of Spain (pp. 215-221). London: The Geological Society.

Rocha, R. B., Mattioli, E., Duarte, L. V., Pittet, B., Elmi, S., Mouterde, R., Cabral, M. C., Comas-Rengifo, M. J., Gómez, J. J., Goy, A., Hesselbo, S. P., Jenkyns, H. C., Littler, K., Mailliot, S., Veiga de Oliveira, L. C., Osete, M. L., Perilli, N., Pinto, S. S., Ruget, C., \& Suan, G. (2016). Base of the Toarcian Stage of the Lower Jurassic defined by the Global Boundary Stratotype Section and Point (GSSP) at the Peniche section (Portugal). Episodes, 39(3), 460-481.

Rosales, I., Quesada, S., \& Robles, S. (2004). Paleotemperature variations of Early Jurassic seawater recorded in geochemical trends of belemnites from the Basque-Cantabrian basin, Northern 
Spain. Palaeogeography, Palaeoclimatology, Palaeoecology, 203(3-4), 253-275.

Ruget, C. (1982). Foraminifères du Lias moyen et supérieur d'Obon (Chaînes Ibériques, Province de Teruel, Espagne). Geobios, 15(1), 53-91.

Ruget, C. (1985). Les foraminifères (Nodosariidés) du Lias de l'Europe Occidentale. Documents des Laboratoires de Géologie de Lyon, 94, 1-273.

Salazar Ramírez, R. W., \& Herrero, C. (2015). Lower Toarcian foraminifera of the San Andrés Section (Basque-Cantabrian Basin, Spain). Journal of Foraminiferal Research, 45(4), 321343. Correction Journal of Foraminiferal Research, 46(1), 95.

Salazar Ramírez, R. W., \& Herrero, C. (2017). Tafonomía de los foraminíferos del Pliensbachiense superior-Toarciense inferior en el sector occidental de la Cuenca Vasco-Cantábrica. In L. O’Dogherty (Coord.), 33 Jornadas de Paleontología, Cádiz. Libro de Resúmenes (pp. 165-167). Cádiz: Sociedad Española de Paleontología.

Salazar Ramírez, R. W., Herrero, C., \& Goy, A. (2015). El Toarciense inferior de San Miguel de Aguayo (Cuenca Vasco-Cantábrica): eventos de foraminíferos y crisis bióticas. In M. Reolid (Ed.), XXXI Jornadas de Paleontología, Baeza. Libro de Resúmenes (pp. 272-274). Jaén: Universidad de Jaén.

Schlatter, R. (1985). Eine bemerkenswerte Ammoniten Fauna aus dem Grenzbereich Pliensbachium / Toarcium der Baar (BadenWürttemberg). Stuttgarter Beiträge zur Naturkunde, 112, 1-27.

Suárez-Vega, L. C. (1974). Estratigrafía del Jurásico en Asturias. Cuadernos de Geología Ibérica, 3, 1-370.

Tremolada, F., Van de Schootbrugge, B., \& Erba, E. (2005). Early Jurassic schizosphaerellid crisis in Cantabria, Spain: Implications for calcification rates and phytoplankton evolution across the Toarcian Oceanic Anoxic Event. Paleoceanography, 20, 1-11.

Venturi, F., \& Ferri, R. (2001). Ammoniti Liassici Dell'Appennino Centrale. Perugia: Città di Castello.

Villalobos, L. (1971). Excursión al corte de Dos Hermanas y sección de Nacedero de Iribas. Cuadernos de Geología Ibérica, 2, 625-630.

Villalobos, L., \& Ramírez del Pozo, J. (1971). Estratigrafía del Jurásico del NW de Navarra. Cuadernos de Geología Ibérica, 2, 541-558. 